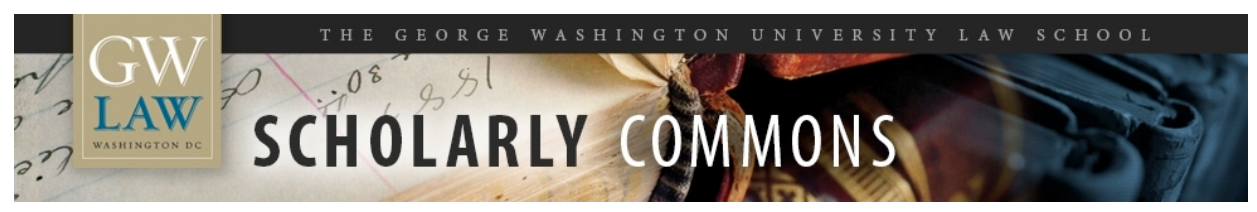

GW Law Faculty Publications \& Other Works

Faculty Scholarship

2011

\title{
The Legacy of Justice Scalia and His Textualist Ideal
}

Jonathan R. Siegel

George Washington University Law School, jsiegel@law.gwu.edu

Follow this and additional works at: https://scholarship.law.gwu.edu/faculty_publications

Part of the Law Commons

\section{Recommended Citation}

Siegel, Jonathan R., The Legacy of Justice Scalia and His Textualist Ideal (May 2017). 85 Geo. Wash. L. Rev. 857 (2017); GWU Law School Public Law Research Paper No. 2017-78; GWU Legal Studies Research Paper No. 2017-78. Available at SSRN: https://ssrn.com/abstract=3068880

This Article is brought to you for free and open access by the Faculty Scholarship at Scholarly Commons. It has been accepted for inclusion in GW Law Faculty Publications \& Other Works by an authorized administrator of Scholarly Commons. For more information, please contact spagel@law.gwu.edu. 


\title{
The Legacy of Justice Scalia and His Textualist Ideal
}

\author{
Jonathan R. Siegel*
}

\begin{abstract}
The late Justice Antonin Scalia reshaped statutory interpretation. Thanks to him, the Supreme Court has become far more textualist. Nonetheless, Justice Scalia never persuaded the Court to adopt his textualist ideal that "the text is the law." In some cases, the Court still gives greater weight to other indicators of statutory meaning, such as perceived statutory purpose. Fundamental institutional features of courts and legislatures-particularly the fact that legislatures act generally and in advance, whereas courts resolve particular questions at the moment a statute is applied-justify this rejection of the textualist ideal.
\end{abstract}

\section{TABle of Contents}

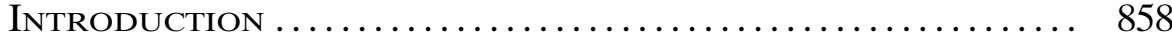

I. Justice Scalia and the Textualist Ideal ......... 861

A. The History of Justice Scalia's Textualist Campaign . 861

B. Assessing Justice Scalia's Impact on Statutory

Interpretation ............................... 869

1. Justice Scalia's Success in Influencing the

Supreme Court's Interpretive Practices ....... 870

2. The Rejection of Justice Scalia's Textualist Ideal ................................. 874

II. KING V. BuRWELl (and YATES V. UNITED STATES) .. 878

$A$. Yates v. United States ........................ 879

B. King v. Burwell .......................... 882

1. The Relevant Statutory Phrase Considered in Isolation ............................ 883

2. The Statutory Phrase Considered in Context ... 885

III. The Significance of King for Statutory

INTERPRETATION AND FOR JUSTICE SCALIA'S

Textualist Ideal .............................. 892

A. King as Continuity, Not Change ............... 893

* Professor of Law and F. Elwood and Eleanor Davis Research Professor of Law, The George Washington University Law School. I thank faculty members at the University of Iowa College of Law, where I presented an earlier draft of this Article, for their valuable comments, and I extend similar thanks to Abbe Gluck.

May 2017 Vol. 85 No. 3 
B. The Source of the Rejection of the Textualist Ideal . .

897

1. Interpretive Difficulties Posed by Pre-"Modern" Statutes ............................... 900

2. Interpretive Difficulties Posed by Statutes Adopted Via the "Orthodox" Legislative Process ................................ 902

3. Interpretive Difficulties Posed by Short Statutes ................................... 905

4. The True Source of the Problem............. 907

C. Statutory Interpretation and the Constitution ....... 909

D. The Future of the Textualist Ideal ................ 915 Conclusion ......................................... 920

\section{INTRODUCTION}

The late Justice Antonin Scalia reshaped statutory interpretation. ${ }^{1} \mathrm{He}$ focused the legal world's attention on the importance of statutory text. Before Justice Scalia came to the Supreme Court, federal courts often displayed a casual attitude toward statutory text, and in the course of interpreting a statute, frequently paid more attention to the statute's purpose and legislative history than to its actual language. ${ }^{2}$ Justice Scalia rebelled against such interpretive methods. ${ }^{3} \mathrm{He}$ made textualism one of his signature issues and waged a sustained, decades-long campaign to promote it. ${ }^{4}$ Justice Scalia had tremendous influence over the interpretive practices of federal courts. Thanks to him, federal courts today generally acknowledge the importance of carefully examining statutory text. ${ }^{5}$

Although Justice Scalia's textualist campaign had tremendous influence, it never achieved its final victory. Notwithstanding all the time and energy he devoted to promoting textualism, Justice Scalia never persuaded the Supreme Court to abandon reliance on legislative history. The Court never ceased to consult statutory purpose. ${ }^{6}$ Most of all, the Court never adopted Justice Scalia's fundamental textualist axiom: "The text is the law."

1 Justice Scalia died February 13, 2016. See Adam Liptak, Antonin Scalia, Justice on the Supreme Court, Dies at 79, N.Y. Times (Feb. 13, 2016), http://www.nytimes.com/2016/02/14/us/ antonin-scalia-death.html?_r=0.

2 See infra Section I.B.

3 See Liptak, supra note 1.

4 See infra Section I.A.

5 See infra Section I.B.

6 See infra Section II.B.2.

7 Antonin Scalia, Common-Law Courts in a Civil-Law System: The Role of United States 
It is important to distinguish between Justice Scalia's textualist ideal and lesser degrees of textualism. There is a difference between believing that statutory text should be an important factor-even the most important factor-in statutory interpretation, and believing that statutory text is the law. Believers in the former view may call themselves textualists, as Justice Kagan recently did in the Scalia Lecture at Harvard Law School. ${ }^{8}$ To Justice Scalia, however, textualism necessarily entailed the latter view. Although Justice Scalia had great success in increasing the weight the Supreme Court and other federal courts give to statutory text in statutory interpretation, he never persuaded them that statutory text simply is the law.

Justice Scalia's lack of success in converting the Supreme Court to his textualist ideal was vividly illustrated in his final full Term as a Justice, as the Court faced a great test of its interpretive methodology in King v. Burwell. ${ }^{9}$ The case concerned the availability of subsidies for those who purchase health insurance on health care exchanges created pursuant to the Patient Protection and Affordable Care Act ("ACA"), ${ }^{10}$ also known as "Obamacare." 11 Although a straightforward reading of the statutory text suggested that such subsidies are available only to those who purchase insurance on state-created health care exchanges, the Court departed from the textualist ideal and read the statute to permit subsidies for those who purchase health insurance on exchanges created by the federal government. ${ }^{12}$

The King decision provides important lessons for statutory interpretation and for the fate of Justice Scalia's textualist ideal. Opponents of the King decision spoke about the case in apocalyptic terms. Columnist George Will said that Chief Justice Roberts had helped to "overthrow the Constitution." ${ }^{13}$ Senator Orrin Hatch suggested that

Federal Courts in Interpreting the Constitution and Laws, in A MATTER OF INTERPRETATION: Federal Courts and the Law 3, 22 (Amy Gutmann ed., 1997) (emphasis added); see also infra Section II.B.

8 Elena Kagan, Assoc. Justice of the U.S. Supreme Court, The Scalia Lecture at Harvard Law School, at min. 18 (Nov. 17, 2015), http://today.law.harvard.edu/in-scalia-lecture-kagan-dis cusses-statutory-interpretation (navigate to embedded video). The "lecture" actually consisted of a colloquy between the Justice and Professor John Manning, and citations to it herein are to the minute in which the cited material was spoken. Although Justice Kagan called herself a textualist, she does not embrace Justice Scalia's textualist ideal. See infra notes 426-27 and accompanying text.

9135 S. Ct. 2480 (2015); see infra Section II.B.

10 Patient Protection and Affordable Care Act, Pub. L. No. 111-148, 124 Stat. 119 (2010).

11 See King, 135 S. Ct. at 2485; see also Orrin G. Hatch, King v. Burwell and the Rule of Law, 63 UCLA L. Rev. Discourse 2, 4, 6 (2015).

12 See infra Section II.B.

13 George F. Will, Opinion, On Obamacare, John Roberts Helps Overthrow the Constitu- 
"the continued vitality of the rule of law" was at stake. ${ }^{14}$ Justice Scalia himself said that under the Court's decision, "[w]ords no longer have meaning." 15

In fact, this Article suggests, King v. Burwell simply makes clear that the Supreme Court has never accepted Justice Scalia's textualist ideal. The Court has always looked to other methods of statutory interpretation. King is a momentous case because of the great stakes involved, but insofar as statutory interpretation is concerned, the case represents more continuity than change. Properly recognizing the interpretive methods used in King as the longstanding methods that they are rebuts the charge that departures from the textualist ideal "overthrow the Constitution." The Constitution permits the courts to use the interpretive methods that they have used for centuries. ${ }^{16}$

The longstanding nature of the interpretive methods used in King also addresses some suggestions by supporters of the decision as to King's significance. In her Harvard Law Review comment on the case, the always-insightful Professor Abbe Gluck suggests that King v. Burwell represents the Supreme Court's reaction to the needs of "modern" lawmaking and "modern" statutes. ${ }^{17}$ She emphasizes the ways in which interpretive difficulties arise from the increasing number of statutes that, like the ACA, go through an "unorthodox" legislative process. ${ }^{18}$ This Article suggests, however, that the real significance of King is its continuity with longstanding interpretive methods. There is nothing particularly "modern" about the need to interpret statutes using methods other than Justice Scalia's textualist ideal. The need to do so arises, not from "modern" lawmaking, but from institutional features of legislatures and courts that are, and always have been, intrinsic to the lawmaking and law-interpreting

tion, WASH. Post (June 25, 2015), https://www.washingtonpost.com/opinions/john-roberts-helpsoverthrow-the-constitution/2015/06/25/47d9ffde-1b67-11e5-93b7-5eddc056ad8a_story.html. Will may not have chosen the wording of the headline, from which the above quotation is taken. But the body of his column states, "The Roberts Doctrine facilitates what has been for a century progressivism's central objective, the overthrow of the Constitution's architecture," id., so the headline is a fair summary of the column.

14 Hatch, supra note 11 , at 4.

15 King, 135 S. Ct. at 2497 (Scalia, J., dissenting); see also Jonathan H. Adler \& Michael F. Cannon, King v. Burwell and the Triumph of Selective Contextualism, 2015 CAto Sup. CT. Rev. 35, 35-36 ("[T]he Court effectively rewrote the statutory text . ...").

16 See infra Section III.C.

17 Abbe R. Gluck, Imperfect Statutes, Imperfect Courts: Understanding Congress's Plan in the Era of Unorthodox Lawmaking, 129 HARv. L. REv. 62, 62, 65 (2015).

18 Id. at 63-65, 97-99. 
processes. ${ }^{19}$ Most notably, the need for interpretation that departs from the textualist ideal arises from the fundamental institutional fact that legislatures act generally and in advance, whereas courts resolve particular questions at the moment a statute is applied. These institutional realities guarantee that legislatures can never produce the degree of perfection in their statutory texts that the textualist ideal demands. They also mean that courts will always have an institutional advantage in detecting and addressing situations in which glossing or departing from statutory text is required. These timeless institutional features, not anything particularly modern, justify the rejection of the textualist ideal. ${ }^{20}$

This Article looks back at Justice Scalia's textualist campaign and assesses its impact, using King as a prime illustration. Part I recounts Justice Scalia's textualist campaign and shows that it had a significant impact on statutory interpretation. Part II examines King and another decision from Justice Scalia's final full Term, Yates v. United States, ${ }^{21}$ which helps to put King in context. Part III assesses the state of statutory interpretation following Justice Scalia's death. Justice Scalia had great influence, but never persuaded the Supreme Court to adopt his textualist ideal. Institutional realities justify the Court's choice. Bereft of its great champion, the textualist ideal is likely to recede in influence.

\section{Justice Scalia and the Textualist Ideal}

Justice Scalia's campaign to promote textualism occupied a considerable portion of his Supreme Court career. ${ }^{22}$ His long-term, highly visible efforts, carried out over decades, had significant influence on the Supreme Court's interpretive methodology. ${ }^{23}$ Yet he never really won the Court over to the textualist ideal. ${ }^{24}$

\section{A. The History of Justice Scalia's Textualist Campaign}

Justice Scalia did not arrive at his textualist position all at once..$^{25}$ His methodological thinking initially focused on the question of

19 See infra Section III.B.

20 See infra Section III.B.

21135 S. Ct. 1074 (2015).

22 See infra Section I.A

23 See infra Section I.B.

24 See infra Section III.D.

25 Professor William Eskridge traced the evolution of Justice Scalia's thinking up to 1990 in his classic article, William N. Eskridge, Jr., The New Textualism, 37 UCLA L. REv. 621, 650-56 (1990). 
whether, in interpreting a statute, courts could appropriately rely on legislative history such as committee reports. ${ }^{26}$ Justice Scalia objected to this practice, but did not initially set forth in his opinions what later became his full-fledged textualist position. ${ }^{27}$ Indeed, some of Justice Scalia's early opinions focused primarily on a pragmatic, realist objection to the use of legislative history and implicitly accepted nontextualist reasoning. ${ }^{28}$ Although his philosophical, formalist position was also in the picture, Justice Scalia's full-fledged textualism emerged only gradually. ${ }^{29}$

Justice Scalia objected to judicial reliance on legislative history while still a D.C. Circuit judge. ${ }^{30}$ Once elevated to the Supreme Court in 1986, he continued this objection. As early as 1987, in the case of INS v. Cardoza-Fonseca, ${ }^{31}$ Justice Scalia objected to the use of legislative history where statutory text was clear and not patently absurd..$^{32}$ He justified his objection on the ground that "[j]udges interpret laws rather than reconstruct legislators' intentions." 33 This formalist objection would, if taken to its logical conclusion, apply to all uses of legislative history.

Other cases from this early period, however, suggest that Justice Scalia had not yet fully embraced the implications of his objections to legislative history. For example, in the 1989 case of Blanchard v. Bergeron,$^{34}$ the Supreme Court faced the question of whether an attorney's fee award under 42 U.S.C. $\$ 1988^{35}$ could exceed the amount that a prevailing plaintiff's attorney would have collected under a contingent-fee arrangement with the plaintiff. ${ }^{36}$ In answering this question in the affirmative, the Court relied on the statute's legislative history. ${ }^{37}$ The Court gave particular weight to some lower court opinions cited

26 Id. at $650-52$.

27 See id. at 651 (noting that, at least initially, Justice Scalia "seemed to accept other legislative history as authoritative in some cases," but opposed treating committee reports as authoritative).

28 See id.

29 Id. at $652-53$.

30 See Hirschey v. FERC, 777 F.2d 1, 7-8 (D.C. Cir. 1985) (Scalia, J., concurring); see also Eskridge, supra note 25, at 650-51.

31480 U.S. 421 (1987). Eskridge focuses on this case particularly in his article, The New Textualism. Eskridge, supra note 25.

32 Cardoza-Fonseca, 480 U.S. at 452 (Scalia, J., concurring in the judgment).

33 Id. at $452-53$.

34489 U.S. 87 (1989).

3542 U.S.C. $\$ 1988$ (1988).

36 Blanchard, 489 U.S. at 89-90.

37 See id. at 91-92, 95. 
in House and Senate reports. ${ }^{38}$ The Court inferred that Congress had endorsed those opinions as guides to the meaning of the statute..$^{39}$

Justice Scalia, in a concurring opinion, objected to the Court's reliance on legislative history. ${ }^{40}$ His objection, however, seems modest when compared to the fervent objections he raised to the use of legislative history in later opinions. He based it on the pragmatic ground that legislative history is an unreliable guide to legislative intent. ${ }^{41} \mathrm{He}$ argued that only a small number of members of Congress would have read the committee reports in question, and that none of them would have read the court opinions that Congress was supposedly endorsing. ${ }^{42} \mathrm{He}$ also complained that such references in the committee reports were inserted by staff-possibly at the behest of lobbyists-for the very purpose of influencing judicial construction of the statute. ${ }^{43}$ For these reasons, Justice Scalia concluded that legislative history was unreliable, and he sternly "decline[d] to participate in th[e] process" of using it as the Court had. ${ }^{44}$

What is most striking about this early opinion is how Justice Scalia couches his arguments in ways that implicitly accept the thendominant intentionalist and purposivist paradigms of statutory interpretation. Indeed, his arguments appear surprising when read today, in light of the later development of his thinking. ${ }^{45}$ Justice Scalia asserted that, because of the unreliability of committee reports, giving weight to them was not "conducive to a genuine effectuation of congressional intent," 46 thereby implicitly accepting the implementation of congressional intent as the goal (or at least as one goal) of statutory interpretation. He complained that committee reports had become "increasingly unreliable evidence of what the voting Members of Congress actually had in mind," 47 thereby implicitly accepting that a court should care what members of Congress have in mind when passing a statute. He joined the part of the Court's opinion that did not rely on

38 See id. at 91-93.

39 Id. The prior cases concerned fee awards under a different statute, see id. at $91 \mathrm{n} .5$, but in light of the citations to them in the legislative history of $\S 1988$, the Court held that these cases provided useful guidance for fee awards under $§ 1988$, $i d$. at 91-92.

40 Id. at 97-100 (Scalia, J., concurring in part and concurring in the judgment).

41 See id. at 98-99.

$42 I d$.

43 Id.

$44 \quad I d$. at 99.

45 See infra note 55 and accompanying text.

46 Blanchard, 489 U.S. at 99 (Scalia, J., concurring in part and concurring in the judgment) (emphasis added).

47 Id. (emphasis added). 
legislative history, which, he said, "admirably follows our more recent approach of seeking to develop an interpretation of the statute that is reasonable, consistent, and faithful to its apparent purpose," 48 thereby implicitly accepting that part of a court's role in statutory interpretation is to interpret a statute so as to be faithful to its apparent purpose.

Justice Scalia's thinking evolved over the next decade. In some cases, he continued with his modest, practical objections to legislative history. He lamented that searches of legislative history were not worth their trouble because they usually failed to uncover anything useful, ${ }^{49}$ and he continued to assert that legislative history was unreliable and manipulable. ${ }^{50} \mathrm{He}$ also singled out particularly inappropriate uses of legislative history for condemnation. For example, he complained about the use of "subsequent" or "post-enactment" legislative history, which he regarded as "a contradiction in terms." ${ }_{51}$ But in some early cases he did not reject legislative history wholesale and even relied on it himself, at least obliquely. ${ }^{52}$

By 1991, Justice Scalia's objections to the use of legislative history started to take on a sharper tone. He questioned the very practice of "utilizing legislative history for the purpose of giving authoritative content to the meaning of a statutory text." ${ }_{53} \mathrm{He}$ asserted that this practice was a recent development. Traditionally, he claimed, the Supreme Court declined to rely on legislative history. He observed that "[a]s late as 1897, [the Court] stated quite clearly that there is 'a general acquiescence in the doctrine that debates in Congress are not appropriate sources of information from which to discover the meaning

48 Id. at 99-100 (emphasis added).

49 See, e.g., Taylor v. United States, 495 U.S. 575, 603 (1990) (Scalia, J., concurring in part and concurring in the judgment).

50 See, e.g., Begier v. IRS, 496 U.S. 53, 67-71 (1990) (Scalia, J., concurring in the judgment) (questioning Representative Edwards's comments on the Congressional Record regarding the Bankruptcy Code versus the Internal Revenue Code).

51 Sullivan v. Finkelstein, 496 U.S. 617, 631-32 (1990) (Scalia, J., concurring in part) (explaining that "subsequent" or "post-enactment" legislative history consists of statements made and materials created in Congress after a statute has been passed and stating that arguments based on subsequent legislative history "should not be taken seriously").

52 See, e.g., Lehnert v. Ferris Faculty Ass'n, 500 U.S. 507, 555-56 (1991) (Scalia, J., concurring in the judgment in part and dissenting in part) ("Our accepted mode of resolving statutory questions would not lead to a construction of $\S 8(\mathrm{a})(3)$ so foreign to that section's express language and legislative history." (quoting Commc'ns Workers v. Beck, 487 U.S. 735, 763 (1988) (Blackmun, J., concurring in part and dissenting in part))); United States v. Owens, 484 U.S. 554, 562-63 (1988) (Scalia, J.) (relying on House and Senate reports).

53 Wis. Pub. Intervenor v. Mortier, 501 U.S. 597, 622 (1991) (Scalia, J., concurring in the judgment). 
of the language of a statute passed by that body. " ${ }^{54}$ In 1992, he referred to legislative history as the "St. Jude of the hagiology of statutory construction" 55 - although even then he did not completely renounce it. ${ }^{56}$ His opinion stressed only that legislative history should not be used to resolve ambiguities in a criminal statute against the defendant. ${ }^{57}$

The following year, however, Justice Scalia objected to what he considered to be the Supreme Court's particularly egregious use of legislative history in Conroy v. Aniskoff. ${ }^{58}$ That case concerned the redemption of real property sold to satisfy tax obligations. A federal statute provided that the time allowed by state law for such redemption must be tolled during a period of military service. ${ }^{59}$ The question was whether, in order to take advantage of this tolling rule, a military member had to show that his service prejudiced his ability to redeem his property. ${ }^{60}$ In holding that the statute imposed no such requirement, the Court stated that the statutory command was "unambiguous, unequivocal, and unlimited." 61 Nonetheless, the Court examined the legislative history of the statute for insight into the statute's meaning, and the Court even relied on the legislative history of predecessor statutes enacted decades before the statute at issue. ${ }^{62}$

Justice Scalia's concurrence strongly objected to this use of legislative history. As in his earlier opinions, Justice Scalia complained that legislative history is flawed because it is indeterminate. ${ }^{63} \mathrm{He}$ said that "[i]f one were to search for an interpretive technique that, on the whole, was more likely to confuse than to clarify, one could hardly find a more promising candidate than legislative history." ${ }^{64}$ To illustrate how serious this problem was, Justice Scalia went into the legislative history of the statute at issue and its predecessor statutes in great

54 Id. (quoting United States v. Trans-Mo. Freight Ass'n, 166 U.S. 290, 318 (1897)).

55 United States v. Thompson/Center Arms Co., 504 U.S. 505, 521 (1992) (Scalia, J., concurring in the judgment). "St. Jude is . . the patron saint of lost causes." Mark R. Killenbeck, $A$ Matter of Mere Approval? The Role of the President in the Creation of Legislative History, 48 Ark. L. Rev. 239, 239 n.2 (1995).

56 See Thompson/Center Arms, 504 U.S. at 521 (Scalia, J., concurring in the judgment); see also United States v. R.L.C., 503 U.S. 291, 307 (1992) (Scalia, J., concurring in part and concurring in the judgment).

57 See Thompson/Center Arms, 504 U.S. at 521 (Scalia, J., concurring in the judgment).

58507 U.S. 511 (1993).

59 Id. at $512-13$.

$60 I d$.

61 Id. at 514.

62 See id. at 514-18, 517 n.11.

$63 I d$. at 519 (Scalia, J., concurring in the judgment).

64 Id. (emphasis removed). 
depth. Justice Scalia assigned a "hapless law clerk"65 the task of showing just how indeterminate legislative history can be, and he spent ten pages discussing the fruits of the clerk's research. ${ }^{66}$

In addition to this complaint about legislative history's indeterminacy, Justice Scalia also sounded a different theme. He said: "The greatest defect of legislative history is its illegitimacy. We are governed by laws, not by the intentions of legislators." ${ }^{67}$ Justice Scalia thus embraced a reason justifying the rejection of all use of legislative history. Moreover, he tied this reason to what became his fundamental interpretive philosophy: textualism. ${ }^{68}$ Casting off his previous, implicit acceptance of the view that implementing legislative intent is the goal of statutory interpretation, Justice Scalia declared that what matters is the law itself, not legislative intent. ${ }^{69}$

Justice Scalia crystalized his thoughts into a set of lectures delivered at Princeton in 1995, which later appeared as an essay published within a book in $1997 . .^{70}$ In the essay, he strongly embraced textualism and rejected intentionalism. ${ }^{71}$ The essay expressed Justice Scalia's usual, particular distaste for judicial reliance on legislative history. ${ }^{72}$ But it made clear that that distaste did not follow merely from practical, methodological difficulties of using legislative history, such as its indeterminacy. ${ }^{73}$ Rather, rejection of legislative history followed from an examination of first principles of statutory interpretation, and in particular from the textualist axiom that " $[\mathrm{t}] \mathrm{he}$ text is the law, and it is the text that must be observed." 74 Justice Scalia claimed that "it is simply incompatible with democratic government, or indeed, even with fair government, to have the meaning of a law determined by what the lawgiver meant, rather than by what the lawgiver promulgated." 75 These points implied that courts should reject reliance on legislative history, but that was merely one detail in the much bigger picture. The bigger picture was the interpretive philosophy of textual-

65 Id. at 527.

66 See id. at 519-28.

67 Id. at 519 (emphasis added).

68 See id. at 528.

69 See id.

70 Scalia, supra note 7, at xii, 3; William N. Eskridge, Jr., Textualism, the Unknown Ideal?, 96 Мich. L. Rev. 1509, 1510 (1998) (reviewing Scalia, supra note 7).

71 See Scalia, supra note 7, at 16-17, 22, 36.

72 See id. at 29-37.

73 See id. at 22.

74 Id. (emphasis added).

75 Id. at 17. 
ism: if there is a conflict between the text of a statute and the intention of the statute's drafter, the text controls. ${ }^{76}$

In his essay, Justice Scalia was careful to disclaim some views that textualism's opponents sometimes associate with it. ${ }^{77} \mathrm{He}$ emphasized that textualism is not "wooden." 78 It should not be confused with "strict constructionism." "79 Statutory text, he said, should be construed neither strictly nor leniently, but "reasonably, to contain all that it fairly means." ${ }^{80}$ Statutory text must, he recognized, be considered in context, for "[i]n textual interpretation, context is everything."

At the end of the day, however, "[t]he text is the law." 82 In particular, this means that if statutory text produces a foolish result, or a result unintended by its drafters, or if the text applies in some way that its drafters did not anticipate, it is still law and must be followed. ${ }^{83}$ If clear statutory text produces a result that is at odds with the statute's apparent overall purpose, the text must nonetheless be followed. Consideration of statutory purpose may help clarify ambiguous text, but it must not cause a court to depart from clear statutory text, because the text is the law. ${ }^{84}$

Justice Scalia tied this axiom directly to the constitutional process for enacting law. He observed that under the Constitution, the process of enacting statutory text through the prescribed legislative process imbues that text with legal force, whether or not legislators understand the text. ${ }^{85}$ Giving effect to the statutory text, and not to legislators' understanding of the text is, Justice Scalia suggested, therefore constitutionally required.

Justice Scalia thus began a firm, sustained campaign for textualist statutory interpretation. As always, legislative history was a particular sticking point. He generally refused to rely on legislative history in his own opinions, ${ }^{86}$ and even when he otherwise joined the Court's opin-

76 See id.

77 See id. at 23-25.

78 Id. at 23.

79 Id.

$80 \mathrm{Id}$.

81 Id. at 37.

82 Id. at 22.

83 See id. at 20 (foolish statutes); id. at 21 (cases where the legislature "overlegislated").

84 See id. at 23; see also King v. Burwell, 135 S. Ct. 2480, 2502 (2015) (Scalia, J., dissenting); Babbitt v. Sweet Home Chapter of Cmtys. for a Great Or., 515 U.S. 687, 725-26 (1995) (Scalia, J., dissenting).

85 Scalia, supra note 7 , at 34-35.

86 Justice Scalia approved a limited use of legislative history in Green v. Bock Laundry Machine Co., 490 U.S. 504 (1989). He stated that where a statutory text led to a result that was so 
ion, he made a point of refusing to join portions that relied on it-a practice that he continued over decades. ${ }^{87}$ More generally, he argued against "the elevation of judge-supposed legislative intent over clear statutory text," ${ }^{8}$ objected to "policy-driven interpretation," 89 denied the existence of judicial "power "to rescue Congress from its drafting errors, $"{ }^{90}$ and generally promoted textualist interpretation.

A final major milestone of Justice Scalia's textualist campaign came in 2012, when, along with Bryan Garner, he published a substantial treatise on statutory interpretation..$^{91}$ The book is largely a compilation of canons of construction, with examples of their use and critical commentary. ${ }^{92}$ But the early sections lay out the authors' textualist philosophy ${ }^{93}$ Like Justice Scalia's 1997 essay, the book is at pains to disclaim caricatures of textualism's rigidity. For example, the book observes that construction of a statute's text may properly be informed by consideration of the statute's purpose and may favor resolving ambiguities in the text in a way that achieves the statute's purpose. ${ }^{94}$ But the book assigns "paramount concern" to the statutory tex ${ }^{95}$ and warns that purpose cannot be used to contradict or supplement the text: "Purpose sheds light only on deciding which of various textually permissible meanings should be adopted." 96

absurd that a court might reform the text under the absurdity doctrine, the court, before reforming the text, should check the legislative history "to verify that what seems to us an unthinkable disposition . . was indeed unthought of." Id. at 527 (Scalia, J., concurring in the judgment).

87 See, e.g., Octane Fitness, LLC v. ICON Health \& Fitness, Inc., 134 S. Ct. 1749, 1752 n.* (2014); Carr v. United States, 560 U.S. 438, 440 (2010); Doe v Chao, 540 U.S. 614, 616 (2004); Nat'l Credit Union Admin. v. First Nat'l Bank \& Tr. Co., 522 U.S. 479, 482 n.* (1998). In each case, the cited material noted that Justice Scalia joined all but a specified portion of the Court's opinion-that portion which relied on legislative history.

88 Zuni Pub. Sch. Dist. No. 89 v. Dep’t of Educ., 550 U.S. 81, 108 (2007) (Scalia, J., dissenting).

89 Id. at $109,116-17$.

90 King v. Burwell, 135 S. Ct. 2480, 2504 (2015) (Scalia, J., dissenting) (quoting Lamie v. U.S. Tr., 540 U.S. 526, 542 (2004)).

91 Antonin Scalia \& Bryan A. Garner, Reading Law: The Interpretation of LeGAL Texts (2012).

92 See id. at 69-339.

93 See, e.g., id. at 15-28, 56-58.

94 See id. at 56.

95 Id.

96 Id. at 57. 


\section{B. Assessing Justice Scalia's Impact on Statutory Interpretation}

Justice Scalia did not invent textualism. ${ }^{97}$ Textualism has always had its adherents, both academic ${ }^{98}$ and judicial. ${ }^{99}$ But he brought it tremendous attention. He made it one of his signature issues, and he gave it increased visibility from his perch on the Supreme Court. His long-term campaign for textualism, which he sustained over a period of decades, put the issue on everyone's agenda. Judges and scholars were forced to reconsider their methods of statutory interpretation. Many who had casually assumed that a court's role is to implement the intent of the legislature were compelled to think critically about their interpretive principles and determine whether they were really true.

An enormous literature sprang up to deal with these issues. Professor William Eskridge noted Justice Scalia's influence early on in his classic article, The New Textualism. ${ }^{100}$ Some academics, such as John Manning and Adrian Vermeule, took up the banner of textualism, developing arguments for it on either formalist ${ }^{101}$ or realist ${ }^{102}$ grounds. Other academics criticized textualism. ${ }^{103}$

In assessing the influence of Justice Scalia on the courts themselves, and particularly on the Supreme Court, it is necessary to distinguish between textualism and what may be called Justice Scalia's textualist ideal. As discussed earlier, the essence of Justice Scalia's textualist ideal was his textualist axiom, "[t]he text is the law." ${ }^{104}$ To

97 Eskridge, supra note 70, at 1511.

98 See, e.g., Max Radin, Statutory Interpretation, 43 HARv. L. REv. 863, 869-72 (1930) (arguing that "legislative intent" is undiscoverable and would be irrelevant if it could be discovered).

99 Justice Holmes, for example, wrote: "We do not inquire what the legislature meant; we ask only what the statute means." Oliver Wendell Holmes, The Theory of Legal Interpretation, 12 Harv. L. Rev. 417, 419 (1899). Justice Jackson quoted this remark approvingly. Schwegmann Bros. v. Calvert Distillers Corp., 341 U.S. 384, 397 (1951) (Jackson, J., concurring).

100 See Eskridge, supra note 25.

101 See, e.g., John F. Manning, Textualism as a Nondelegation Doctrine, 97 Colum. L. REv. 673,673 (1997) (arguing that the constitutional rule against congressional self-delegation prohibits judicial reliance on legislative history, which amounts to allowing Congress to delegate power to its committees).

102 See, e.g., Adrian Vermeule, Judging Under Uncertainty: An Institutional TheOry of Legal Interpretation 10-11 (2006) (arguing that judges should employ textualism because other methods cannot be shown to yield benefits that justify their costs).

103 See, e.g., Veronica M. Dougherty, Absurdity and the Limits of Literalism: Defining the Absurd Result Principle in Statutory Interpretation, 44 Am. U. L. REv. 127, 128, 158-59 (1994); Melvin Aron Eisenberg, Strict Textualism, 29 Loy. L.A. L. REv. 13, 14 (1995); William N. Eskridge, Jr., All About Words: Early Understandings of the "Judicial Power" in Statutory Interpretation, 1776-1806, 101 Colum. L. Rev. 990, 991-98 (2001).

104 Scalia, supra note 7 , at 22. 
Justice Scalia, textualism meant that a court must follow statutory text even when the text yields a foolish, unintended, or unanticipated result, or a result that detracts from the statute's apparent overall purpose. ${ }^{105}$ There can be no doubt that Justice Scalia's textualism was tremendously influential. At the same time, this Article suggests, the courts never accepted Justice Scalia's textualist ideal, which remains a minority view within the judiciary.

\section{Justice Scalia's Success in Influencing the Supreme Court's Interpretive Practices}

Justice Scalia undoubtedly changed the Supreme Court's interpretive practices. His long-term, persistent textualist campaign reminded everyone of the importance of statutory text. His influence can be seen quantitatively in technical measures, such as the Court's increased reliance on dictionaries, which reached its highest rate in history at the turn of the twenty-first century. ${ }^{106}$ It can also be seen qualitatively in the way the Court consults legislative history. On the one hand, the Court still does so; on the other hand, Justice Scalia has clearly made the Court rather self-conscious about it. When it consults legislative history, the Court often does so somewhat apologetically. In the recent case of T-Mobile South, LLC v. City of Roswell, ${ }^{107}$ for example, the Court included a legislative history argument "for those who consider legislative history relevant." 108 This or similarly apolo-

105 See Whitfield v. United States, 135 S. Ct. 785, 789 (2015) (statute's text applies, even if the actual case is not what Congress had most prominently in mind); King v. Burwell, $135 \mathrm{~S}$. Ct. 2480, 2501-02 (2015) (Scalia, J., dissenting) (clear statutory text applies even if at odds with statutory purpose); Babbitt v. Sweet Home Chapter of Cmtys. for a Great Or., 515 U.S. 687, 725-26 (1995) (Scalia, J., dissenting) (same); ScAlia \& GARner, supra note 91, at 101 (general words in a statute must be given their general meaning, even if that entails application to cases that the statute's drafters never contemplated); Scalia, supra note 7, at 20-21 (foolish statutes, and cases where the legislature "overlegislated").

Justice Scalia did accept one circumstance in which the text was not the law: where the result indicated by the text was absurd. See Scalia, supra note 7, at 20-21. As I and others have previously discussed, the absurd results exception is the Achilles' heel of textualism, for it acknowledges that every case involves extratextual considerations. Jonathan R. Siegel, Textualism and Contextualism in Administrative Law, 78 B.U. L. REv. 1023, 1100 (1998). But for purposes of this Article, the point is that even if one believes the textualist ideal can remain coherent if it is leavened by the absurd results exception, the Supreme Court never accepted that textualist ideal. It continued its practice of approving departures from statutory text even in cases where the textual result was not absurd.

106 Jeffrey L. Kirchmeier \& Samuel A. Thumma, Scaling the Lexicon Fortress: The United States Supreme Court's Use of Dictionaries in the Twenty-First Century, 94 MARq. L. Rev. 77, 85 (2010).

107135 S. Ct. 808 (2015)

108 Id. at 815 . 
getic expressions have become increasingly common when the Court cites legislative history. ${ }^{109}$

Most of all, Justice Scalia's effect on the Court's interpretive methodology can be seen by comparing the general way the Court goes about construing statutes now with the way it did so before Justice Scalia's arrival on the Court. In cases from the 1960s and 1970s, the Court often gave itself up to wholly unrestrained reliance on legislative history and statutory purpose, scouring congressional reports far more closely than statutory text. For example, in construing 42 U.S.C. $\S 1983^{110}$ during this period, the Court did not just consult legislative history, it exulted in legislative history. In Monell v. Department of Social Services of City of New York, ${ }^{111}$ the Supreme Court considered whether a municipality is a "person" subject to suit under $\S 1983$. With barely a glance at the relevant statutory text (the Court mentioned that the question was whether a municipality is a statutory "person" but provided no textual analysis), ${ }^{112}$ the Court launched into an "analysis of the debate on the Civil Rights Act of 1871" that was so long it had to begin with an overview. ${ }^{113}$ The Court devoted eighteen pages to recounting congressional debates leading up to the Act. ${ }^{114}$ Then the Court finally turned to the textual question of whether the term "per-

109 See, e.g., Warger v. Shauers, 135 S. Ct. 521, 527 (2014) ("For those who consider legislative history relevant, here it confirms that this choice of language was no accident."); FTC v. Actavis, Inc., 133 S. Ct. 2223, 2234 (2013) ("Those interested in legislative history may also wish to examine the statements of individual Members of Congress . . . ."); Kirtsaeng v. John Wiley \& Sons, Inc., 133 S. Ct. 1351, 1361 (2013) ("[F]or those who find legislative history useful, the relevant legislative report makes this clear.”); Match-E-Be-Nash-She-Wish Band of Pottawatomi Indians v. Patchak, 132 S. Ct. 2199, 2207 n.5 (2012) ("The legislative history, for those who think it useful, further shows [what the statute addresses]."); Tapia v. United States, 564 U.S. 319, 331 (2011) ("[F]or those who consider legislative history useful, the key Senate Report . . . provides one last piece of corroborating evidence.”); United States v. Tinklenberg, 563 U.S. 647, 659 (2011) ("[F]or those who find legislative history useful, it is worthwhile noting . . the Senate Report . . ."); Barber v. Thomas, 560 U.S. 474, 485 (2010) (“[T]hose who consider legislative history significant cannot find that history helpful to petitioners here.").

Justice Kagan stated in her recent Scalia Lecture that the Court uses these expressions to permit Justice Scalia to join the opinion as a whole, without his customary disclaimer that he did not join the portion of the opinion relying on legislative history. Kagan, supra note 8, at min. 23. However, in some of the cases cited, Justice Scalia did not join the Court's opinion anyway, so the use of these expressions suggest that Justice Scalia's critique of legislative history has made the Court more self-conscious about its use. See Actavis, 133 S. Ct. at 2223; Kirtsaeng, 133 S. Ct. at 1351 .

\footnotetext{
11042 U.S.C. $\$ 1983$ (2012).

111436 U.S. 658 (1978).

$112 I d$. at 662.

$113 \mathrm{Id}$. at 665.

114 See id. at 665-83.
} 
son" includes municipalities, ${ }^{115}$ but even as to that question it gave legislative history equal billing with textual analysis. It said that "[a]n examination of the debate on $\S 1$ and application of appropriate rules of construction show unequivocally that $\S 1$ was intended to cover legal as well as natural persons." 116 Finally, after six more pages devoted mostly to recounting legislative debates, the Court concluded that "[o]ur analysis of the legislative history of the Civil Rights Act of 1871 compels the conclusion that Congress did intend municipalities and other local government units to be included among those persons to whom § 1983 applies.” 117 The Court engaged in similarly lavish examinations of legislative history in other $\S 1983$ cases. ${ }^{118}$

Tennessee Valley Authority v. Hill ("TVA") 119 provides another well-known example of interpretive techniques common to this period. The question was whether the Endangered Species Act ${ }^{120}$ prohibited the operation of a dam that would wipe out the endangered snail darter, notwithstanding that the dam had, at great expense, already been virtually completed. ${ }^{121}$ Although the Court started with the statutory text, which it found to be plain and to admit of no exception, ${ }^{122}$ the Court spent nearly twenty pages examining the legislative reports and other legislative history before concluding that the statutory text meant what it said. ${ }^{123}$

Perhaps nowhere was the Court's attitude toward legislative history during this period better epitomized than in the 1971 case of Citizens to Preserve Overton Park, Inc. v. Volpe. ${ }^{124}$ In that case, the Court had to determine the meaning of a statutory command that the Secretary of Transportation not approve the use of federal funds in the construction of a highway through a public park unless no "feasible and prudent" alternative route existed. ${ }^{125}$ In analyzing whether this statutory standard permitted the Secretary to consider a wide range of factors, including the cost and disruption required to avoid destruction of

115 See id. at 683.

116 Id. (emphasis added).

117 Id. at 690 (emphasis removed).

118 See, e.g., Monroe v. Pape, 365 U.S. 167, 172-87 (1961) (devoting fifteen pages to analyzing legislative history, primarily floor statements, in concluding that actions taken "under color of" state law include actions that violate state law).

119437 U.S. 153 (1978).

12016 U.S.C. $\$ \S 1531-1544$ (2012).

121 See Tenn. Valley Auth., 437 U.S. at 156, 161, 166.

122 Id. at 173.

123 See id. at 174-93.

124401 U.S. 402 (1971).

125 Id. at 405. 
parkland, ${ }^{126}$ the Court made a remark that seems incredible today: "The legislative history of [the relevant statutes] is ambiguous. . . Because of this ambiguity it is clear that we must look primarily to the statutes themselves to find the legislative intent." ${ }^{127}$ Truly, as Justice Scalia later complained, the legal culture of the period was such that "lawyers routinely ... ma[d]e no distinction between words in the text of a statute and words in its legislative history." 128

The Supreme Court does not do this kind of thing today. Instead, statutory text is far more prominent on the Court's interpretive agenda. The Court consults legislative history, but does not bathe in it for dozens of pages. The Court feels obliged to examine and respect statutory text far more than it did before Justice Scalia's arrival. Certainly, the days when a lawyer could make no distinction between words in statutory text and words in legislative history are over.

Consider, for example, the Supreme Court's recent decision in Bilski v. Kappos, ${ }^{129}$ an important case about patentable subject matter. The case tested whether a business method can be patented under the Patent Act's ${ }^{130}$ authority for patenting a "process." 131 The Supreme Court's reasoning on this question contrasted starkly with the long history of judicial interpretation of the patent statute. ${ }^{132}$ For well over a century, the Supreme Court and lower courts interpreted the patent statute with a rich awareness of the history, policies, and background understandings of the patent system, which frequently caused the courts to gloss, strain, and even depart from the statutory text. ${ }^{133}$ In Bilski, by contrast, the Supreme Court simply consulted "dictionary definitions" and "common usage" with regard to the relevant statutory terms, "process" and "method," 134 and buttressed its analysis with application of the interpretive canon against statutory redundancy. ${ }^{135}$

126 See id. at $411-12$.

127 Id. at 412 n.29.

128 Scalia, supra note 7, at 31; cf. Amalgamated Meat Cutters \& Butcher Workmen v. Connally, 337 F. Supp. 737, 750 (D.D.C. 1971) (three-judge district court opinion) ("Whether legislative purposes are to be obtained from committee reports, or are set forth in a separate section of the text of the law, is largely a matter of drafting style.").

129561 U.S. 593 (2010).

13035 U.S.C. $\$ \S 1-376(2012)$.

131 Bilski, 561 U.S. at 597-98 (quoting 35 U.S.C. $§ 101$ ).

132 For a detailed discussion of this case, see Jonathan R. Siegel, Nä̈ve Textualism in Patent Law, 76 BRook. L. Rev. 1019 (2011).

133 See id. at 1020-24 (providing numerous examples of cases in which the Supreme Court and other courts interpreted the patent statute in nontextualist ways).

134 Bilski, 561 U.S. at 603, 606-07. The Patent Act defines "process" to mean "process, art or method." 35 U.S.C. $\S 100$.

135 Bilski, 561 U.S. at 607-08. 
Gone were appeals to history, policy, and background understandings. ${ }^{136}$

Today, cases like Bilski are far more common than cases like Monell or TVA. As Justice Kagan observed in her recent Scalia Lecture, statutory interpretation has changed from a policy-oriented inquiry into "what should this statute be?" to an inquiry into what the words on the statutory paper say. ${ }^{137}$ Even the Justices who are least textualist, Justice Kagan said, now start with the statutory text, ${ }^{138}$ and "Justice Scalia had more to do with this than anybody."139

So there can be no doubt that Justice Scalia had a substantial effect on the Supreme Court's interpretive methodologies. Thanks to Justice Scalia, the initial focus of statutory interpretation is on statutory text. To the extent that textualism means no more than that, it can be said, as Justice Kagan said (and as I said as early as 1998), "we're all textualists now." 140

\section{The Rejection of Justice Scalia's Textualist Ideal}

At the same time, it seems equally clear that Justice Scalia's long textualist campaign never achieved its ultimate goal. The Supreme Court never accepted Justice Scalia's textualist ideal. We are all textualists now if textualism means no more than that interpretation of a statute should start with its text, but to Justice Scalia, textualism meant much more than that. To Justice Scalia, textualism was not simply a set of soft principles such as: "Start with the statutory text and give it principal consideration"; "Be skeptical of legislative history"; "Remember that no statute pursues its purposes at all costs"; and "Follow the statutory text unless there is a good reason to do something else." 141 The essence of Justice Scalia's textualist ideal was his textualist axiom, "[t]he text is the law." ${ }^{142}$ To Justice Scalia, textualism meant that a court must follow statutory text even when the text

136 Justice Kennedy's opinion made some policy arguments, but only in a section that did not attract enough votes to be the opinion of the Court. See id. at 605-06 (Kennedy, J.).

137 Kagan, supra note 8, at min. 5.

138 Id . at min. 8 (referring to Justice Breyer as "a little bit of an outlier," but saying that even he starts with the text).

139 Id. at min. 5.

140 Id. at min. 8; Siegel, supra note 105, at 1057.

141 See generally Larry M. Eig, Cong. Research Serv., 97-589, Statutory Interpretation: General Principles and Recent Trends 3-4, 41-43 (2011) (discussing principles of statutory interpretation, including textualist principles).

142 Scalia, supra note 7 , at 22. 
yields a foolish, unintended, or unanticipated result, or a result that detracts from the statute's apparent overall purpose. ${ }^{143}$

The Supreme Court, however, has never accepted this ideal. The Court has long recognized that although statutory text is usually the law, sometimes it isn't. Sometimes, the force of other considerations, such as legislative history, statutory purpose, sound policy, or background principles of law, convinces the Court to gloss, strain, or even depart from statutory text, no matter how clear the text is. Although, as the previous Section showed, the Supreme Court's interpretive methods underwent important changes after Justice Scalia came to the Court, ${ }^{144}$ the Court's rejection of the textualist ideal remained constant.

As an example of the Court's attitude toward the textualist ideal in the pre-Scalia period, consider the classic cases of United States $v$. Storer Broadcasting Co. ${ }^{145}$ and Federal Power Commission v. Texaco, Inc. ${ }^{146}$ two important administrative law cases. In each of these cases, a statute textually commanded an administrative agency to grant a hearing to any party whose application for a license the agency denied. The statute at issue in Storer Broadcasting was particularly clear. It instructed the Federal Communications Commission ("FCC"), upon receiving an application for a broadcast license, to determine whether granting the license would serve the "public interest, convenience, and necessity," and if it so found, to grant the license. ${ }^{147}$ If, however, the agency did not grant the license, the agency was required to "formally designate the application for hearing." 148 Moreover, the statute provided, "[a]ny hearing subsequently held upon such application shall be a full hearing in which the applicant and all other parties in interest shall be permitted to participate." 149

Despite this pellucidly clear statutory text, the Supreme Court approved the FCC's practice of not setting an application for hearing when the application failed to meet a mandatory requirement set forth in the agency's rules. ${ }^{150}$ The Court said:

\footnotetext{
143 See supra note 105.

144 See supra Section I.B.1.

145351 U.S. 192 (1956).

146377 U.S. 33 (1964). I previously discussed these cases in Siegel, supra note 105, at

14747 U.S.C. $\$ 309$ (a) (1952); Storer, 351 U.S. at 195 n.5.

14847 U.S.C. $\$ 309$ (b) (emphasis added).

149 Id. (emphasis added).

150 Storer, 351 U.S. at 202-03.
} 1045-50. 
We do not read the hearing requirement ... as withdrawing from the power of the Commission the rulemaking authority necessary for the orderly conduct of its business.

... The Communications Act must be read as a whole and with appreciation of the responsibilities of the body charged with its fair and efficient operation. ${ }^{151}$

The Court also remarked that "[w]e do not think Congress intended the Commission to waste time on applications that do not state a valid basis for a hearing." ${ }_{152}$ The Texaco case was similar. ${ }^{153}$

Thus, in each case, the Supreme Court disregarded clear statutory text. One who accepted the textualist ideal that statutory text is the law, even where it commands foolish or unintended results, would have been obliged to say that the agency in each case was required to hold a hearing on the rejected applications, silly and futile though such hearings would be. But the Supreme Court did not do this. Storer and Texaco exemplify the Supreme Court's longstanding practice of giving priority to background principles of law over statutory text. ${ }^{154}$ In these cases, the Court gave weight to the background principle that the purpose of administrative hearings is to receive evidence regarding contested facts, not to argue points of law. ${ }^{155}$ A hearing is therefore inappropriate when no facts are contested. This principle was so important that it overrode the clear statutory text commanding a hearing. ${ }^{56}$

Of course, Storer and Texaco were decided in the pre-Scalia era. But decades of Justice Scalia's textualist campaign did not dislodge the practices that these cases embody, nor persuade the Court to adopt the textualist ideal. This can be seen from Justice Scalia's own

151 Id.

152 Id. at 205.

153 Section 7(c) of the Natural Gas Act originally provided that "[w]henever any naturalgas company shall make an application for a certificate of convenience and necessity under the provisions of this subsection, the [Federal Power] Commission shall set the matter for hearing." Natural Gas Act, Pub. L. No. 75-688, ch. 556, § 7(c), 52 Stat. 821, 825 (1938) (emphasis added). By the time of the Texaco case, the Act had been amended to provide that the Commission would automatically issue a certificate if an application met certain conditions, which were not met in the case at hand. "In all other cases," the statute provided, "the Commission shall set the matter for hearing." 15 U.S.C. $\$ 717 \mathrm{f}(\mathrm{c})$ (1964) (emphasis added). Nonetheless, the Supreme Court approved the Commission's practice of denying an application without hearing if the application was for a contract that contained provisions forbidden by the Commission's rules. See Texaco, 377 U.S. at 35, 39.

154 For a thorough discussion of how these cases illustrate this point, see Siegel, supra note 105 , at $1045-49$.

155 Id. at 1046.

156 Id. at $1046-47$. 
opinions. Justice Scalia promoted textualism to the end of his days, but he was frequently forced to do so in separate dissents or concurrences in which he took the Court to task for departing from statutory text. ${ }^{157}$ Notwithstanding Justice Scalia's views, the Supreme Court was still willing to gloss statutory text in light of legislative history, perceived legislative purpose, or for some other reason, to avoid foolish, unintended results.

Consider, for example, the recent case of Zuni Public School District No. 89 v. Department of Education. ${ }^{158}$ The case concerned a statute governing federal aid to state education. Under the statute, a state that "equalize[d] expenditures" among its school districts was entitled to certain favorable treatment with regard to its federal aid. ${ }^{159}$ The legal question at issue in Zuni concerned the method the federal Secretary of Education was required to use in determining whether a state "equalize[d] expenditures." 160 A particular school district thought the Secretary was not using the required method, and the Supreme Court acknowledged the strength of the school district's argument based on "the literal language of the statute." 161 The Court nonetheless ruled for the Secretary on the basis of the history and purpose of the statute. ${ }^{162}$ Indeed, it took the unusual step of analyzing the history and purpose prior to considering the statutory text. ${ }^{163}$ In light of the statute's purpose and history, the Court construed the statutory language to permit the Secretary's practices. ${ }^{164}$

Justice Scalia wrote a spirited dissent. He said that the case was "an exemplar of judicial disregard of crystal-clear text." $165 \mathrm{He}$ pressed his fundamental argument that the text is the law: "I do not believe," he said, "that what we are sure the Legislature meant to say can trump

157 See, e.g., King v. Burwell, 135 S. Ct. 2480, 2496-97 (2015) (Scalia, J., dissenting); Am. Broad. Cos. v. Aereo, Inc., 134 S. Ct. 2498, 2515 (2014) (Scalia, J., dissenting); Lawson v. FMR LLC, 134 S. Ct. 1158, 1176-77 (2014) (Scalia, J., concurring in principal part and concurring in the judgment); DePierre v. United States, 564 U.S. 70, 89 (2011) (Scalia, J., concurring in part and concurring in the judgment); Zuni Pub. Sch. Dist. No. 89 v. Dep't of Educ., 550 U.S. 81, 108 (2007) (Scalia, J., dissenting); Stewart v. Martinez-Villareal, 523 U.S. 637, 646-47 (1998) (Scalia, J., dissenting); Babbitt v. Sweet Home Chapter of Cmtys for a Great Or., 515 U.S. 687, 714-17 (1995) (Scalia, J., dissenting).

158550 U.S. 81 (2007). For a thorough discussion of this case, see Jonathan R. Siegel, The Inexorable Radicalization of Textualism, 158 U. PA. L. REv. 117, 161-68 (2009).

159 Zuni, 550 U.S. at 84-85.

$160 I d$. at 86. For a detailed discussion, see Siegel, supra note 158, at 161-68.

161 Zuni, 550 U.S. at 89.

162 Id. at 93.

$163 I d$. at 90-93.

164 Id. at 93-100.

165 Id. at 122 (Scalia, J., dissenting). 
what it did say." ${ }^{166}$ But Justice Scalia's opinion was a dissent. He made the case for adopting the textualist ideal, but the Court rejected it. ${ }^{167}$ And Zuni is just one of numerous similar cases. ${ }^{168}$ As Part II demonstrates, the Court continued to reject Justice Scalia's textualist ideal right up to his final years.

\section{KING V. BURWELl (ANd Yates V. United STATES)}

The inability of Justice Scalia's textualist campaign to persuade the Court to adopt the textualist ideal was vividly illustrated in his final full Term on the Court. As the prime illustration, this Article examines the case that posed the great test of statutory interpretation in the year before Justice Scalia's death: King v. Burwell. Before examining King, however, this Part first considers a different, less notable case. The reason for doing this is that King was a "great case." The stakes involved were enormous. Billions of dollars in federal spending hung on the outcome, and a loss for the government could have spelled doom for President Obama's signature domestic initiative. As Justice Holmes famously remarked, "[g]reat cases like hard cases make bad law," because the overwhelming importance of a case "appeals to the feelings and distorts the judgment." 169 Studying King alone might be misleading, if in King the Court bent its usual interpretive principles to reach a result it felt was demanded by the importance of the case-as, indeed, the dissent accused it of doing. ${ }^{170}$ This Part begins, therefore, with a much less notable case, Yates $v$. United States. Studying the interpretive methods used in this routine case puts the great case of King in a useful context.

166 Id. at 119.

167 I must note that it is also possible that the Court rejected not Justice Scalia's textualist methodology, but his analysis of the particular statutory text at hand. I have previously explained that there was perhaps just enough ambiguity in the statutory text at issue in Zuni to justify the Court's decision to uphold the agency's interpretation on the basis of Chevron deference. See Siegel, supra note 158, at 167 n.280. But there is no doubt that the statutory text, severed from intentionalist and purposivist analysis, favored Justice Scalia's interpretation, and there was at least some argument that the Court departed from unambiguously clear text. See id. In any event, the Court clearly rejected Justice Scalia's argument that it was wrong to place so much weight on statutory history and purpose.

168 See cases cited supra note 157.

169 N. Sec. Co. v. United States, 193 U.S. 197, 400 (1904) (Holmes, J., dissenting).

170 See King v. Burwell, 135 S. Ct. 2480, 2506-07 (2015) (Scalia, J., dissenting). 


\section{A. Yates v. United States}

John Yates was the captain of a commercial fishing vessel. ${ }^{171}$ When he and his crew were fishing in federal waters, they were boarded by an inspector, who discovered undersized fish on board (federal regulations required that fish below a certain length be thrown back). ${ }^{172}$ The inspector put the undersized fish in some crates and told Yates to keep the fish in the crates until the ship came ashore. ${ }^{173}$ When the ship came ashore, however, the fish were missing-Yates had ordered a crew member to throw the fish overboard, destroying the evidence that he had violated the fishing regulations. ${ }^{174}$

Yates was charged with and convicted of one crime that made sense: taking action to impair the government's lawful authority to take property into its custody. ${ }^{175}$ Yates was also, however, charged under the Sarbanes-Oxley Act. ${ }^{176}$ This charge might come as a surprise to those familiar with the statute. The Sarbanes-Oxley Act was passed to combat corporate financial fraud; $; 17$ it seems remote from fish being thrown overboard. Nonetheless, the charge appeared justified in light of the actual statutory language of the Act, codified at 18 U.S.C. $§ 1519$, which provides, in relevant part: "Whoever knowingly alters, destroys, mutilates, conceals, covers up, falsifies, or makes a false entry in any record, document, or tangible object with the intent to impede ... [a federal investigation], shall be fined under this title, imprisoned not more than 20 years, or both." 178 The government asserted that Yates had done exactly what this statute prohibits: he had knowingly "destroy[ed]" or "conceal[ed]" "tangible object[s]"namely, the fish-in order to impede a federal investigation. ${ }^{179}$

The question whether fish are "tangible objects" within the meaning of the statute went to the Supreme Court. Four Justices (including Justice Scalia) thought the case a simple one. These Justices observed that if one looks up the words "tangible" and "object" in a dictionary, one discovers that fish are tangible objects. ${ }^{180}$ Although

171 Yates v. United States, 135 S. Ct. 1074, 1079 (2015) (plurality opinion).

172 Id.

173 Id.

174 Id. at $1079-80$.

175 Id. at 1078-79 (quoting 18 U.S.C. § 2232(a) (2012)).

176 Id.; Sarbanes-Oxley Act of 2002, Pub. L. No. 107-204, 116 Stat. 745 (codified as amended in scattered sections of 15 and 18 U.S.C.).

177 Yates, 135 S. Ct. at 1081.

17818 U.S.C. $\S 1519$ (emphasis added); see Yates, 135 S. Ct. at 1078.

179 See Yates, 135 S. Ct. at 1080.

180 Id. at 1091 (Kagan, J., dissenting). 
recognizing that dictionary definitions are not invariably controlling and that words must be taken in context, ${ }^{181}$ these Justices saw no reason to depart from the ordinary, dictionary meaning here.

In particular, these Justices thought it irrelevant whether Congress had fish in mind when it passed the Sarbanes-Oxley Act. Congress is not required to contemplate every application of its statutes in advance, and Congress may, indeed, choose a catchall term like "tangible objects" for the very purpose of covering things not specifically contemplated. ${ }^{182}$ This reasoning is appropriate to the textualist ideal, under which statutory text is the law, regardless of what any legislator had in mind while voting for it.

However, the other five Justices (a four-Justice plurality and one concurring Justice) saw the case differently. Although recognizing that fish are within the dictionary definition of the phrase "tangible object" if one considers those two words in isolation, ${ }^{183}$ the plurality emphasized that a court does not consider statutory words in isolation, but rather in the context provided by the statute as a whole. ${ }^{184}$ That context, the plurality suggested, provided several indications that as used in the Sarbanes-Oxley Act, the words "tangible object" have a narrower meaning that does not include fish. ${ }^{185}$

A significant part of the context, the plurality indicated, was the overall purpose of the Sarbanes-Oxley Act. ${ }^{186}$ The plurality observed at the start of its opinion that the Sarbanes-Oxley Act was "designed to protect investors and restore trust in financial markets following the collapse of Enron Corporation." 187 To read the statute to cover any and all tangible objects would be to "cut [the statute] loose from its financial-fraud mooring." 188 Thus, the plurality's perception of the overall purpose of the statute colored its understanding of the statute's particular provisions. ${ }^{189}$

The plurality also relied on several textual indications that suggested a narrower meaning of the phrase "tangible object." The plurality noted, for example, that the list of verbs at the start of $\S 1519$

181 Id. at 1092.

182 Id. at $1099-1100$.

183 Id. at 1079,1081 (plurality opinion) ("A fish is no doubt an object that is tangible ....").

184 See id. at 1081-82.

185 Id.

186 See id. at 1079, 1087.

187 Id. at 1079.

188 Id.

189 See id. at 1087 (relying on the fact that the statute "target[ed] fraud in financial recordkeeping"). 
includes "falsifies" and "makes a false entry in." 190 These verbs make sense only with objects used to store information; one could hardly "falsify" or "make a false entry in" a fish. ${ }^{191}$

The plurality also noted that the statutory phrase at issue was not simply "tangible object," but "record, document, or tangible object." 192 This point implicates two interpretive principles so venerable that they have names in Latin: noscitur a sociis, which provides that a "word is known by the company it keeps," 193 and ejusdem generis, which provides that when a general term comes at the end of an enumerated list of specific terms, the general term is to be understood as more general than, but still similar in nature to, the specific terms. ${ }^{194}$ Thus, the plurality concluded, within the phrase "record, document, or tangible object" in $\S 1519$, the term "tangible object" should be understood to mean tangible objects that are similar to records or documents-specifically, tangible objects in which information can be stored. The phrase would cover, for example, a computer's hard drive, but not a fish. ${ }^{195}$

Unlike King v. Burwell, Yates was not a grand, high-stakes case. It was a routine case that garnered little public attention. But for precisely this reason, Yates usefully illustrates the methods of statutory interpretation that the Supreme Court ordinarily and routinely uses. Three lessons are evident in Yates.

First, when called upon to interpret a particular statutory term or phrase such as "tangible object," courts should not consider the phrase in isolation, but rather in the context provided by the overall statute of which the phrase is a part. This is not controversial; it is a completely standard principle of interpretation. Even the textualist dissent in Yates agreed with it. ${ }^{196}$

Second, when considering statutory text in context, part of the context is the overall purpose of the statute. The plurality relied on its understanding of the overall purpose of the Sarbanes-Oxley Act. ${ }^{197}$

190 Id. at 1086 (emphasis removed) (quoting 18 U.S.C. $§ 1519$ (2012)).

191 See id.

19218 U.S.C. $\S 1519 ;$ see Yates, 135 S. Ct. at 1085-86.

193 Yates, 135 S. Ct. at 1085.

194 Id. at 1086; see also SCAlia \& Garner, supra note 91, at 199.

195 See Yates, 135 S. Ct. at 1086. The plurality also relied on other textual arguments. See id. at 1083-88. Justice Alito, the concurring Justice, eschewed reliance on the overall statutory purpose, but was persuaded by the textualist arguments noted in the text above and by the limited title of § 1519: "Destruction, alteration, or falsification of records in Federal investigations and bankruptcy." Id. at 1089-90 (Alito, J., concurring in the judgment) (quoting 18 U.S.C. § 1519).

196 Id. at 1092 (Kagan, J., dissenting).

197 See id. at 1079, 1087 (plurality opinion). 
Statutory purpose is part of the statutory context. This point is more controversial. To Justice Scalia, statutory purpose may shed light on the meaning of ambiguous statutory text, but can never change the meaning of clear statutory text. ${ }^{198}$

Finally, when a court considers a statutory term or phrase in the context provided by the statute as a whole, including the statutory purpose, it will happen sometimes-not all the time, not even most of the time, but sometimes - that such consideration will lead the court to give the term or phrase a meaning other than the most obvious, straightforward meaning that it would have if considered in isolation. ${ }^{199}$ Indeed, if this were not true, there would be no point to considering terms in context. If context could not cause a court to deviate from the meaning a term would have in isolation, the court would do better simply to consider the term in isolation. Everyone agrees, however, that statutory terms must be considered in context. It must, therefore, be the case that the context can have a real effect on a term's meaning. ${ }^{200}$ Thus, in Yates, the two words "tangible object," considered in isolation, are broad enough to encompass a fish, but considered in the full statutory context-particularly including the apparent statutory purpose - they were best understood to have a narrower meaning.

Yates usefully illustrates that the Court routinely deploys these contextual principles of statutory interpretation. And there are dozens-if not scores or hundreds-of cases like Yates, stretching back through the decades and the centuries. ${ }^{201}$ The common use of these interpretive techniques goes a long way toward answering the charge that the techniques are unconstitutional. ${ }^{202}$ The routine case of Yates provides a useful context for the blockbuster case of King v. Burwell.

\section{B. King v. Burwell}

King v. Burwell concerned the subsidies provided by the ACA to help people at lower income levels buy health insurance. There was a problem, however, in the way Congress wrote the statutory provision providing these subsidies. As foreshadowed by Yates, how a court should deal with this problem depends on whether the court should consider the statutory phrase most particularly at issue in isolation or

198 See, e.g., King v. Burwell, 135 S. Ct. 2480, 2502 (2015) (Scalia, J., dissenting).

199 See, e.g., Yates, 135 S. Ct. at 1081-82 (plurality opinion).

200 See supra Section I.B.

201 For examples, see infra Sections III.B, III.C.

202 For more on this point, see infra Section III.C. 
whether the court should consider that statutory phrase in the context provided by the statute as a whole. The problem presented in King is best understood by first carefully considering the statutory text of the subsidy provision in isolation and then considering it in the context provided by the full statute.

\section{The Relevant Statutory Phrase Considered in Isolation}

The subsidy provision, 26 U.S.C. $\S 36 \mathrm{~B}$, although part of the ACA, is codified within the tax code and provides: "In the case of an applicable taxpayer, there shall be allowed as a credit . . . an amount equal to the premium assistance credit amount ...."203 Thus, a person entitled to a subsidy under the ACA receives that subsidy as a tax credit. ${ }^{204}$ To understand the meaning of $\S 36 \mathrm{~B}$, one must understand the meaning of the two terms it uses: "applicable taxpayer," and "premium assistance credit amount." 205 "Applicable taxpayer" is easy: elsewhere, $\S 36 \mathrm{~B}$ defines this term to mean a taxpayer whose household income is from 100 to 400 percent of the poverty line. ${ }^{206}$

"Premium assistance credit amount," however, is more complex. ${ }^{207}$ Section 36B defines the premium assistance credit amount for the year as the sum of the "premium assistance amounts" for each of the taxpayer's "coverage months." 208 It is therefore necessary to know what the "premium assistance amounts" are-and therein lies the problem. Section 36B defines the "premium assistance amount" as the lesser of two possible amounts:

The premium assistance amount ... is the amount equal to the lesser of-

(A) the monthly premiums for ... 1 or more qualified health plans offered in the individual market within a State which cover the taxpayer ... and which were enrolled in through an Exchange established by the State under 1311 of the Patient Protection and Affordable Care Act, or . . . . 209

20326 U.S.C. $\$ 36 B(a)$ (2012).

204 The ACA subsidies are thus provided as a "tax expenditure"; that is, the ACA's tax code provisions reduce eligible taxpayers' taxes for policy reasons unrelated to measuring their net income. Andy S. Grewal, King v. Burwell: Where Were the Tax Professors?, 2015 PePP. L. REV. 48, 50.

20526 U.S.C. $\$ 36 \mathrm{~B}(\mathrm{a})$.

206 Id. $\S 36 \mathrm{~B}(\mathrm{c})(1)(\mathrm{A})$.

207 See id. § 36B(b)(1).

208 Id.

209 Id. $\S 36 \mathrm{~B}(\mathrm{~b})(2)$. 
As will become clear in a moment, it is unnecessary to consider the other possible amount. By virtue of the phrase "the lesser of," the premium assistance amount cannot be more than the amount defined by the text just quoted.

What does this provision mean? In simpler words, it means that a person can never receive a subsidy that is more than the person's total health insurance premiums. The other relevant amount under the provision (not quoted above) may well limit a person's subsidy further, so that the purchaser gets only a partial subsidy, ${ }^{210}$ but certainly the maximum possible subsidy is the total amount a person has to pay for health insurance.

However, as written, the provision also imposes some important limits on the receipt of subsidies. First, subsidies are available only toward the purchase of "qualified" health plans, which are extensively regulated elsewhere in the ACA. ${ }^{211}$ Second, and more important, a subsidy is available only for a qualified health plan "enrolled in through an Exchange established by the State under 1311" of the ACA. ${ }^{212}$

This second requirement implicates an important feature of the ACA. The Act apparently requires each state to create a health care exchange through which its residents can purchase health insurance. It says that "[e]ach State shall, not later than January 1, 2014, establish an American Health Benefit Exchange." ${ }^{213}$ However, Congress knew that it could not really require states to create health care exchanges to implement the ACA, as such a requirement would violate the federalism principle that prevents Congress from "commandeering" state executive officials to execute federal law. ${ }^{214}$ Therefore, although stating that each state shall create a health care exchange, ${ }^{215}$ the ACA also provides that in the event a state fails to do so, "the Secretary [of Health and Human Services ("HHS")] shall . . establish and operate such Exchange within the State." 216 In actual practice under the ACA in 2015 , only sixteen states had created their own health care ex-

210 See id.

211 See id. $\S 36 \mathrm{~B}(\mathrm{c})(3)(\mathrm{A}) ; 42$ U.S.C. $\S 18021$ (2012) (containing additional regulation of "qualified" health plans).

21226 U.S.C. $\S 36 \mathrm{~B}(\mathrm{~b})(2)(\mathrm{A})$.

21342 U.S.C. § 18031(b)(1) (emphasis added).

214 Printz v. United States, 521 U.S. 898, 925 (1997).

21542 U.S.C. § 18031(b)(1).

216 Id. $\S 18041(\mathrm{c})(1)$. 
changes. ${ }^{217}$ In the other thirty-four states, there were health care exchanges, but they were created by the federal government. ${ }^{218}$

Therefore, the plain language of $\S 36 \mathrm{~B}$, quoted above, appears to say that in states that have not created their own health care exchange, the premium assistance amount can never be more than zero. The language quoted above states that the premium assistance amount cannot be more than the total premiums for a qualified health plan enrolled in through "an Exchange established by the State." In states where there is no exchange established by the state, the total premium for qualified health plans enrolled in through "an Exchange established by the State" is necessarily zero.

This was the plaintiffs' argument in King v. Burwell. ${ }^{219}$ If one considers the text of $\S 36 \mathrm{~B}$ in isolation, the plaintiffs' argument is a good one, ${ }^{220}$ but the plaintiffs were subjected to considerable criticism. Commentators claimed that the plaintiffs were deliberately attempting to "pull the statute apart by concentrating on 'bits and pieces of the law.'" ${ }^{221}$ However, it is hardly crazy to claim that when interpreting a statute, a court should read the text and do what it says. Indeed, one might ask, how could a court do anything else?

\section{The Statutory Phrase Considered in Context}

The Supreme Court did something else by considering the case very differently from the analysis in the previous Section. From the beginning of its opinion, the Court showed the importance of considering the contested statutory phrase not in isolation, but in the context of the full statute, including the overall statutory purpose. In the very first sentence of the opinion, the Court stated: "The Patient Protection and Affordable Care Act adopts a series of interlocking reforms designed to expand coverage in the individual health insurance market."222

217 King v. Burwell, 135 S. Ct. 2480, 2487 (2015).

218 Id.

219 Id. at 2495.

220 Even the Supreme Court majority ultimately agreed that the plaintiffs had a good textual argument. See id.

221 E.g., Gluck, supra note 17, at 63-64 (quoting Am. Enter. Inst., Who's in Charge? More Legal Challenges to the Patient Protection and Affordable Care Act, YouTube 1:31:45 (Mar. 11, 2014), http://www.youtube.com/watch?\&v=C7nRpJURvE4 (remarks of Michael Greve on the ACA)).

222 King, 135 S. Ct. at 2485. 
This opening sentence called attention to the importance of understanding the "overall statutory scheme" of the ACA. ${ }^{223}$ The Court spent several pages examining the overall statutory scheme before even turning to the particular contested phrase at issue. ${ }^{224}$

The ACA is a huge, complex statute, but it basically does three key things. First, the Act prohibits health insurers from charging customers different prices based on health status. This was the main goal of the statute: to end insurers' practice of denying health insurance, or charging more money, based on customers' pre-existing health conditions. ${ }^{225}$ To achieve this goal, the Act requires insurers to issue insurance to every person who applies for it (the "guaranteed issue" requirement), ${ }^{226}$ and prohibits insurers from charging customers different premiums based on the state of their health (the "community rating" requirement). ${ }^{227}$

The ACA then adds something else: the "individual mandate," which is the requirement that individuals either maintain health insurance or pay a tax penalty to the IRS. ${ }^{228}$ Unlike the popular guaranteed issue and community rating provisions, the individual mandate is burdensome and unpopular. ${ }^{229}$ However, as the Supreme Court recognized, it would be impossible to implement the guaranteed issue and community rating provisions without the individual mandate, because if that were tried (as it was at the state level in several states in the 1990s), the insurance system would collapse. ${ }^{230}$ The reason is simple: if there were no individual mandate, but insurance providers were bound by the guaranteed issue and community rating provisions, then most healthy people would not buy health insurance. It would not be in a healthy person's economic interest to pay premiums for health insurance given that the person could buy insurance at the same price if and when he or she got sick. Therefore, only sick people would buy insurance, insurance companies would not make money because they

223 Id. at 2489 (quoting FDA v. Brown \& Williamson Tobacco Corp., 529 U.S. 120, 133 (2000))

224 See id. at 2485-87.

225 Id. at 2485.

22642 U.S.C. $§ 300$ gg-1(a) (2012); see King, 135 S. Ct. at 2486 (referring to this section as the "guaranteed issue" requirement).

22742 U.S.C. $\$ 300 \operatorname{gg}(\mathrm{a})(1)$; see King, 135 S. Ct. at 2486 (referring to this section as the "community rating" requirement).

22826 U.S.C. $§ 5000 \mathrm{~A}(\mathrm{a})-(\mathrm{b})(1)$ (2012); see King, 135 S. Ct. at 2502 (referring to this section as the "famous individual mandate").

229 See Henry J. Kaiser Family Found., Kaiser Health Tracking Poll: March 2014 5, 13 (2014), https://kaiserfamilyfoundation.files.wordpress.com/2014/03/8565-t2.pdf.

230 King, 135 S. Ct. at 2485-86. 
would pay out more in benefits than they received in premiums, and premiums would have to rise to make up for it. As a result, even fewer people would buy insurance, and premiums would have to rise even further. In short, without the individual mandate, the guaranteed issue and community rating requirements would cause a health insurance "death spiral." ${ }^{231}$ The individual mandate is therefore essential to the statutory scheme.

Finally, to make the individual mandate function, the ACA provides subsidies to help those who could not otherwise afford to comply with the mandate. ${ }^{232}$ These subsidies are particularly important given that, under the statute, the individual mandate does not apply to people who would have to pay more than eight percent of their income for health insurance. ${ }^{233}$ Without the availability of subsidies, so many people would be exempt from the individual mandate that the insurance market would face the very "death spiral" that the mandate was designed to avoid. ${ }^{234}$

Thus, as the Court noted, the reforms are truly "interlocking." 235 Insurance nondiscrimination, the individual mandate, and subsidies make up the three-legged stool that is the ACA. Pull out any one of the legs, and the stool collapses. Insurance nondiscrimination is the primary goal, the individual mandate is essential to make insurance nondiscrimination work, and subsidies are essential to make the individual mandate work.

The fourth and final relevant part of the statute is the ACA's directive that the states (or the Secretary of HHS) set up health care exchanges. ${ }^{236}$ Unlike the three critical, interlocking features of the statute discussed above, this feature is primarily administrative. The exchanges provide a mechanism by which people who do not receive health insurance through their employer can comply with the individual mandate. ${ }^{237}$ Exchanges also provide a mechanism through which the government can administer the ACA's subsidies.238

231 Id. at 2486.

232 See 42 U.S.C. $\S \$ 18081-18082$.

23326 U.S.C. $\$ 5000 \mathrm{~A}(\mathrm{e})(1)$. The eight-percent test applies to the amount a person would have to pay out of pocket, in addition to any subsidy. Id. $\S 5000 \mathrm{~A}(\mathrm{e})(1)(\mathrm{B})(\mathrm{ii})$.

234 King, 135 S. Ct. at 2493-94.

235 Id. at 2485.

236 See 42 U.S.C. $\S \S 18031(b)(1), 18041(b)-(c)(1)$.

237 Id. $\S 18031(\mathrm{~b})(1)$.

238 See id. $\S 18082$. 
The Supreme Court explained all of this statutory structure before even quoting the contested text of the statute. ${ }^{239}$ The structure of the Court's opinion highlights the great importance the Court gave to understanding the statutory context. A full appreciation of the overall structure of the statute is essential to understanding any particular section of statutory text.

Upon considering the statutory text, the Court candidly admitted that the plaintiffs had a strong argument about the plain meaning of $\S 36 \mathrm{~B} .{ }^{240}$ As in Yates, however, the Court determined that the meaning of the text was not so clear when considered "in [its] context and with a view to [its] place in the overall statutory scheme." 241 Looking carefully at the full text of the whole statute, the Court found several indications that the meaning of $\S 36 \mathrm{~B}$ was not as clear as it might seem at first sight.

Two such indications were particularly important. The first was in the statutory provision directing the establishment of the federal exchanges. As noted above, the ACA directs each state to create a health care exchange, but it also provides that if a state fails to do so, the exchange in that state shall be created by the Secretary of HHS. ${ }^{242}$ The precise language of this latter command is: "If . . . a State [fails to establish an Exchange] ... the Secretary [of HHS] shall . . . establish and operate such Exchange within the State . . .."243

Thus, if a state fails to establish a health care exchange for itself, the ACA directs the Secretary of HHS to establish, not merely an exchange for the state, but such exchange for the state. This language, the Court noted, suggests that the federally created exchange is to be equivalent to a state exchange: it is to "meet the same requirements, perform the same functions, and serve the same purposes. . . State and Federal Exchanges should be the same." 244 The phrase "such Exchange" suggests that where the federal government creates an exchange, it is to be deemed the equivalent of a state exchange.

This suggestion was bolstered by other usages of the phrase "established by the State," or an equivalent phrase, throughout the ACA. ${ }^{245}$ In other places, the statute uses these phrases in a context that clearly encompasses exchanges created by the federal govern-

\footnotetext{
239 King, 135 S. Ct. at 2485-87.

240 Id. at 2490, 2495.

241 Id. at 2492 (quoting Util. Air Regulatory Grp. v. EPA, 134 S. Ct. 2427, 2441 (2014)).

24242 U.S.C. $\S \S 18031(\mathrm{~b})(1), 18041(\mathrm{~b})-(\mathrm{c})(1)$.

243 Id. $\$ 18041(\mathrm{c})(1)$ (emphasis added).

244 King, 135 S. Ct. at 2489, 2491.

245 Id. at 2491; see, e.g., 42 U.S.C. § 18031(f)(3).
} 
ment. ${ }^{246}$ For example, the ACA provides that "[a]n Exchange shall make available qualified health plans to qualified individuals and qualified employers," 247 and it provides that "[t]he term "qualified individual' means, with respect to an Exchange, an individual who ... resides in the State that established the Exchange."248 If the phrase "the State that established the Exchange" were interpreted with the same stringency that the plaintiffs demanded for the phrase "established by the State" in $\S 36 \mathrm{~B}$, it would follow that there could be no "qualified individuals" in states with federal exchanges. ${ }^{249}$ The statute, however, "clearly contemplates that there" shall be qualified individuals in every state. ${ }^{250}$ If there were not, a state's exchange could not comply with its statutory duty to "make available qualified health plans to qualified individuals." 251 This and other, similar usages suggest that the phrase "Exchange established by the State" encompasses federally created exchanges. ${ }^{252}$

Putting these and other textual indications together, ${ }^{253}$ the Court concluded that "Exchange established by the State," the critical statutory phrase, "is properly viewed as ambiguous." 254 Although it could be limited to exchanges actually created by states, it could also encompass federally created exchanges. And once this is recognized, it is clear that the latter reading is to be preferred, because the latter is the reading that makes the statute work. ${ }^{255}$ Reading "Exchange estab-

246 The government's brief compiled numerous such usages. See Brief for the Respondents at 27-31, King, 135 S. Ct. 2480 (No. 14-114).

24742 U.S.C. $\S 18031(\mathrm{~d})(2)(\mathrm{A})$.

248 Id. § 18032(f)(1)(A).

249 King, 135 S. Ct. at 2490.

$250 \mathrm{Id}$.

25142 U.S.C. $\S 18031(\mathrm{~d})(2)$.

252 King, 135 S. Ct. at 2490-91.

253 This Article does not detail every textual point relied on by the Court. For others, see King, 135 S. Ct. at 2489-92. The main point is not whether King was correctly decided, but the case's significance for statutory interpretation methodology.

254 Id. at 2491.

255 Of course, one might have expected that once the Court determined that the statute was ambiguous, it would have deferred to the interpretation placed on the statute by the agency entrusted with its enforcement, under the deference principle of Chevron U.S.A. Inc. v. Natural Resources Defense Council, Inc., 467 U.S. 837, 842-44 (1984). In fact, the Court invoked an exception to Chevron deference that it had cited only once before: that Chevron deference does not apply in an extraordinary case where the statutory question is so momentous that the court cannot believe that Congress delegated the question to an administrative agency for decision. King, 135 S. Ct. at 2488-89 (quoting FDA v. Brown \& Williamson Tobacco Corp., 529 U.S. 120, 159 (2000)). The application of this principle in King is significant, first, because it confirms that the "extraordinary case" principle really is a principle of administrative law and that Brown \& Williamson was not merely a one-off case, and, second, because it means the interpretation of 
lished by the State" to encompass federal exchanges is the reading that does not pull out one leg of the Act's three-legged stool and cause the entire structure of the statutory scheme to collapse. A reading that would do that must be disfavored, for, as the Court put it, "[w]e cannot interpret federal statutes to negate their own stated purposes." 256

The Court also observed that if Congress had really meant to render the statute dysfunctional in states that failed to create their own health care exchanges (perhaps in order, as the plaintiffs suggested, to coerce states into creating them), it would have done so more clearly. It seems implausible that Congress would accomplish this goal by stating that subsidies shall be available on exchanges, but then providing obliquely, in "a sub-sub-sub section of the Tax Code," that in states that have not created their own exchanges, the amount of the subsidy shall be zero. ${ }^{257}$ As the Court put it-slyly drawing on an opinion by Justice Scalia- "Congress 'does not alter the fundamental details of a regulatory scheme in vague terms or ancillary provisions." "258 Justice Scalia had expressed the same thought even more memorably by saying that Congress "does not . . . hide elephants in mouseholes." 259

As one might imagine, Justice Scalia's dissent focused primarily on what he regarded as the plain text of the statute. The essence of the dissent is easily summed up:

In order to receive any money under $\S 36 \mathrm{~B}$, an individual must enroll in an insurance plan through an "Exchange established by the State." The Secretary of Health and Human Services is not a State. So an exchange established by the Secretary is not an exchange established by the State-which means people who buy health insurance through such an exchange get no money under $\S 36 \mathrm{~B} .{ }^{260}$

Justice Scalia agreed that the key statutory text must be taken in context, ${ }^{261}$ but determined that the context of the Act undermined rather

the ACA in King cannot be changed in the future by a new administration. Gluck, supra note 17, at 95; see also Jonathan Siegel, Obamacare's Grave Danger: Here's How a Future GOP President Could Kill It, SAlon (Aug. 18, 2014, 7:43 AM), http://www.salon.com/2014/08/18/obamacares_grave_danger_heres_how_a_future_gop_president_could_kill_it/.

256 King, 135 S. Ct. at 2493 (quoting N.Y. State Dep’t. of Soc. Servs. v. Dublino, 413 U.S. 405, 419-20 (1973)).

257 Id. at 2495.

258 Id. (quoting Whitman v. Am. Trucking Ass'ns, Inc., 531 U.S. 457, 468 (2001)).

259 Whitman, 531 U.S. at 468.

260 King, 135 S. Ct. at 2496-97 (Scalia, J., dissenting).

261 Id. at 2497. 
than supported the Court's reading. ${ }^{262} \mathrm{He}$ argued that considerations of statutory purpose cannot overcome clear statutory text. ${ }^{263}$

Justice Scalia also made fundamental philosophical points. $\mathrm{He}$ said that the Constitution gives Congress the legislative power and that the Court's judicial power is only "the power to pronounce the law as Congress has enacted it." $264 \mathrm{He}$ reiterated that "we are governed by the terms of our laws, not by the unenacted will of our lawmakers." 265 And yet this appeal to the textualist ideal garnered only three votes. ${ }^{266}$

The Court's opinion in King v. Burwell thus firmly rejects Justice Scalia's textualist ideal. Equally firmly, it embraces the view that particular statutory text must be interpreted in the overall context of the statute of which it is a part, and that this context includes the overall statutory purpose. ${ }^{267}$ An interpretation of particular statutory text that negates a statute's overall purpose is strongly disfavored. ${ }^{268}$

One might argue that both King and Yates represent not a rejection of Justice Scalia's textualist ideal, but a debate about how to apply it. In neither case did the Court (or in Yates, the plurality) expressly claim to be applying extratextualist interpretive techniques. The Court (or plurality) felt obliged in both cases to come up with some textual explanation for its holding - a strained one, perhaps, but a purportedly textual explanation all the same. The Court (or plurality) considered the particular statutory text at issue in the context of the full statute, but textualists support that practice and indeed recognize that "context is everything." 269 And although the Court (or plurality) gave weight to overall statutory purpose in both cases, even Justice Scalia recognized that a court may consider statutory purpose in construing otherwise ambiguous statutory text. ${ }^{270}$ Perhaps, therefore, one could argue that the Court in both cases applied what it perceived to be textualism; the majority Justices simply differed with the dissenters as to what results textualism demanded. Indeed, Justice Ka-

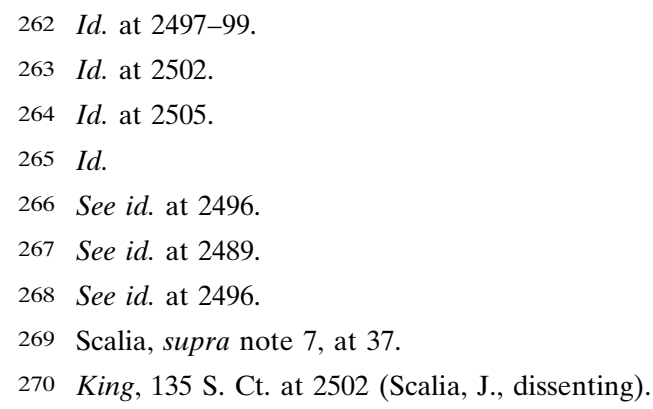


gan calls herself a textualist even though she joined the majority in King. ${ }^{271}$

Still, the cases, although purporting to rely on textualist techniques, are not compatible with the textualist ideal that the text is the law. The textualist ideal does not permit context or purpose to detract from clear statutory text. It is one thing to interpret ambiguous text in light of context or purpose; it is another to depart from clear text when context or purpose make the interpreter suspect that the text is not well drafted. A believer in the textualist ideal does not flinch when a statutory provision's textual meaning seems at odds with the statute's apparent overall purpose. Such an interpreter simply observes that statutes do not do everything that serves their overall purposes. ${ }^{272}$ For believers in the textualist ideal, arguments from statutory purpose are suspect, because the textualist ideal posits that statutory text is the law whether or not it succeeds in serving a purpose. The Court's willingness to read statutory text in an artificial way when necessary to further statutory purpose shows that the Court is prioritizing something other than the belief that the text is the law. Certainly the Court, in both cases, chose statutory readings that departed from the most obvious and straightforward textual readings. Indeed, Justice Kagan has remarked that even if she lived to be 150 , she would never understand how the Court reached its conclusion in Yates, ${ }^{273}$ and, as already noted, Justice Scalia protested that "[w]ords no longer have meaning" under the Court's decision in King. ${ }^{274}$ Thus, although the Court, as a result of Justice Scalia's great influence, feels obliged to find some kind of textual hook to justify its results, the Court does not apply his textualist ideal.

\section{The Significance of King for Statutory}

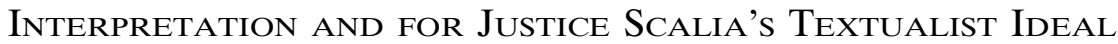

As previously noted, some commentators view King in apocalyptic terms. They assert that the Supreme Court violated the rule of law and overthrew the Constitution. ${ }^{275}$ Others, supporting the result in King, see it as the Court's response to the era of "modern" lawmak-

271 Kagan, supra note 8, at min. 18.

272 See, e.g., Babbitt v. Sweet Home Chapter of Cmtys. for a Great Or., 515 U.S. 687, 725-26 (1995) (Scalia, J., dissenting).

273 Kagan, supra note 8, at min. 42.

274 King, 135 S. Ct. at 2497 (Scalia, J., dissenting).

275 See supra text accompanying notes 13-15. 
ing, which is particularly characterized by "unorthodox" legislative processes. $^{276}$

In fact, King represents far more continuity than change. King is simply a demonstration of the Supreme Court rejecting, as it has long rejected, Justice Scalia's textualist ideal. King uses longstanding interpretive methods that can be found in Hart and Sacks's classic Legal Process materials. ${ }^{277}$ King was of great importance because of the enormous stakes involved, but it did not break new ground in terms of statutory interpretation methodology. ${ }^{278}$ In addition, the methods used in King were not made necessary by "modern" lawmaking or "unorthodox" legislative processes. The interpretive problems posed by the ACA are the same problems that the courts have long faced. These problems arise not from anything peculiarly modern, but from fundamental institutional features of legislatures and courts that have always been with us. ${ }^{279}$ Moreover, the Supreme Court, in dealing with these problems, stayed within its constitutional role. The Court did no more than it has done routinely in statutory cases for decades-indeed, for centuries. The methods used in King are within the "judicial Power" that the Constitution grants to the federal courts. ${ }^{280}$

King suggests that the great battle over interpretive methodology is drawing to a close. Justice Scalia both won and lost. He won in that he substantially modified the way in which the Supreme Court goes about interpreting statutes-he got it to pay far more attention to statutory text. But he lost in that the Supreme Court never accepted his textualist ideal that "[t]he text is the law." 281 With Justice Scalia gone, there is no Justice left who seems likely to carry on his textualist campaign with anything like his vigor and persistence. It seems likely that Justice Scalia's textualist ideal died with him..$^{282}$

\section{A. King as Continuity, Not Change}

In interpreting the ACA in King, the Supreme Court used standard interpretive techniques of a kind that it uses routinely. The Court departed from the textualist ideal, but not because King was a huge case and the Court could not stomach the result that would follow from reading the statute textually, nor because the Court "change[d]

\footnotetext{
276 See supra notes 17-18 and accompanying text.

277 See infra note 285 and accompanying text.

278 See infra Section III.A.

279 See infra Section III.B.

280 See infra Section III.C.

281 Scalia, supra note 7, at 22.

282 See infra Section III.D.
} 
the usual rules of statutory interpretation for the sake of the Affordable Care Act." 283 The Court departed from the textualist ideal because it has never accepted the textualist ideal. It departs from that ideal in innumerable cases.

The Court's decision in Yates helps to show that King represents continuity rather than change. Part II of this Article starts with Yates rather than King because Yates puts King in context. The plurality in Yates, like the Court in King, departed from the most textualist reading of a statute because that reading did not square with its perception of the statutory purpose. ${ }^{284}$ Yates shows that this is a standard interpretive technique, not one invented for the occasion in King. The Justices use purposive interpretation in routine cases that attract little attention (such as Yates) and great cases that are of enormous importance and on which vital social programs and billions of dollars in federal spending hang (such as King).

The interpretive techniques used in both Yates and King come straight out of Henry Hart and Albert Sacks's book on the legal process. $^{285}$ One lesson of the Hart and Sacks book is that before doing something foolish in the name of supposedly plain statutory text, a court should, at a minimum, read the statutory text again and see if it is really as plain as it appears at first glance.

Consider an example that Hart and Sacks develop in detail. The authors criticize a nineteenth-century English decision in a case in which a person was convicted under a statute that made it a crime to fraudulently "personate any person entitled to vote at [an] election." 286 The defendant had voted in the name of someone who was on the voter rolls, but who had died before the election. ${ }^{287}$ The appellate court held that the case was not within the text of the statute. Because the defendant had voted in the name of a deceased person, the court held, he had not personated "a person entitled to vote." 288

283 King v. Burwell, 135 S. Ct. 2480, 2506 (2015) (Scalia, J., dissenting).

284 Although the invocation of statutory purpose came from only a plurality of the Court in Yates, other recent cases show the Court making similar use of statutory purpose. See, e.g., Zuni Pub. Sch. Dist. No. 89 v. Dep't of Educ., 550 U.S. 81, 90-91 (2007); infra text accompanying note 327.

285 Henry M. Hart, Jr. \& Albert M. Sacks, The Legal Process: Basic Problems in the Making and Application of Law 1112-14 (William N. Eskridge, Jr. \& Philip P. Frickey eds., 1994). In her comment on King, Professor Gluck emphasizes the Court's use of methods of the Legal Process school. See Gluck, supra note 17, at 66, 89-90.

286 HART \& SACKS, supra note 285, at 1116-17 (quoting Whiteley v. Chappell (1868) 4 Q.B 147 , at 147).

287 Id. at 1117.

288 Id. at 1118. 
As Hart and Sacks observe, under the court's interpretation, it is difficult to imagine the purpose with which Parliament passed the statute. It is hard to see why Parliament would have wanted to criminalize the fraudulent impersonation of an enrolled, living voter, while in effect saying, "but nothing herein shall be construed to impair the sacred right of a freeborn Englishman to try to swing an election, willfully and fraudulently, by impersonating a voter once duly enrolled but since deceased." 289 In light of the lack of intelligible purpose of the statute as interpreted by the court, Hart and Sacks suggest that an interpreter should have asked whether the statute was really as plain as it appeared. ${ }^{290}$ On rereading the statute carefully, an interpreter might have asked: "Does 'personating any person entitled to vote' have to mean impersonating a particular flesh-and-blood individual? Can it not mean 'pretending to have the character or quality of being entitled to vote when you are not'?" 291 A careful rereading of the statutory text might have revealed that it would bear a more sensible interpretation.

In both Yates and King, the Justices acknowledged the apparently straightforward meaning of the statutory text, but reread that text carefully because the straightforward meaning did not square with their perception of the statutory purpose. ${ }^{292}$ On rereading the text carefully, the Justices found that it was not so clear as it might appear at first glance. In Yates, the plurality arrived at a different reading of the text by deploying canons of construction, particularly ejusdem generis. ${ }^{293}$ In King, the Court justified its reading by latching onto the phrase "such Exchange" elsewhere in the statute, which established ambiguity in the statute's meaning. ${ }^{294}$ In each case, the key step was rereading the statute carefully after determining that the most straightforward, textualist reading produced a result at odds with the perceived statutory purpose.

Of course, this raises the important question of how a court is to determine statutory purpose. In King the Court was able to rely on a "findings" section in the statute itself that expressly set forth the avoidance of the health insurance death spiral as the purpose of the

289 Id.

290 See id. at 1121-22.

291 Id. at 1122.

292 See King v. Burwell, 135 S. Ct. 2480, 2490 (2015); Yates v. United States, 135 S. Ct. 1074, 1081-82 (2015) (plurality opinion).

293 Yates, 135 S. Ct. at $1086-87$.

294 King, 135 S. Ct. at 2489, 2491. 
individual mandate. ${ }^{295}$ But Yates shows that such express codification of statutory purpose is not required. The plurality determined, without any such express statutory provision, that the purpose of the Sarbanes-Oxley Act was to protect investors in the wake of the Enron scandal. ${ }^{296}$ Together, the cases show that whether statutory purpose is expressly codified or (as is more usually the case) not, a conflict between statutory text and perceived statutory purpose can be the impetus that causes the court to read the statutory text again carefully.

One may sense that the Court got lucky in King. It seems unlikely that whoever drafted the fateful phrase "such Exchange" intended it to bear all the weight that the Court later placed on it. ${ }^{297}$ If the statute had commanded the federal government to create "an Exchange" for states that did not create their own, rather than "such Exchange," the Court's linguistic challenge would have been more formidable. But that is what happens when a court rereads a statute's text carefully to see if it is really so clear as to provide no escape from a foolish result; sometimes the court gets lucky. Given that the statutory problem was created by a phrase ("established by the State") that seems equally unlikely to have been intended to bear the weight that the dissent placed on it, the Court may be forgiven for seizing on the "such Exchange" language that rescued the ACA.

If Congress had directed the federal government to create "an Exchange," rather than "such Exchange," for a state that did not create an exchange for itself, the Supreme Court might have had to acknowledge more forthrightly that the crucial text of the ACA is likely a drafting error, and to consider the important question of how great a drafting error a court can repair. ${ }^{298}$ Even in this hypothetical variant, the Court might well have reached the same result. Although the Court sometimes says that it has no power to rescue Congress from its drafting errors, ${ }^{299}$ other cases show that exercising some degree of error-correcting power is a long-established (if not always expressly acknowledged) practice. ${ }^{300}$ In this case, the strong clash between the

$295 I d$. at 2493 (quoting 42 U.S.C. § 18091(2)(I) (2012)).

296 Yates, 135 S. Ct. at 1079.

297 Professor Gluck explains that the language of the ACA resulted from the merger of drafts by two different Senate committees that shared jurisdiction over most of the Act's subject matter. Gluck, supra note 17, at 76-79. Awkwardness resulting from the merger of these two drafts should have been cleared up in a conference committee after each house of Congress voted on the bill, but, because of the unusual process by which the Act was adopted, the conference never occurred. $I d$. at 78 .

298 See id. at 101-05.

299 See, e.g., Lamie v. U.S. Tr., 540 U.S. 526, 542 (2004).

300 See, e.g., United States v. Granderson, 511 U.S. 39, 41-43 (1994); id. at 68 (Kennedy, J., 
statutory text and the statutory purpose, combined with the other statutory usages of the phrase "established by the State" (or an equivalent) in contexts that clearly encompassed federal exchanges, might have been enough for the Court to interpret $\S 36 \mathrm{~B}$ as it did.

In any event, the main point is that the Court invented no new method of statutory interpretation for King. The Court routinely reads a statute in light of its purpose. When the most straightforward reading of the statutory text produces a foolish result at odds with that purpose, the Court reads the statute again. The text may not be as clear as it seems at first sight. As Justice Kagan recently put it in the Scalia Lecture: "If your understanding of some word or phrase would produce some result that seems pretty nuts[,] . . . ask yourself whether you're appropriately looking." ${ }^{301}$ Whether the case be great or small, these principles are a key part of arriving at sound interpretations of statutes.

\section{B. The Source of the Rejection of the Textualist Ideal}

Why has the Supreme Court rejected the textualist ideal, in King and elsewhere? Professor Abbe Gluck, throughout her comment on King, stresses the role that the "modern legislative context" played in the decision. ${ }^{302}$ She repeatedly emphasizes the way in which King represents the Supreme Court's reaction to "modern statutory complexity" and the modern rise in "unorthodox lawmaking." 303

Professor Gluck's comment does not focus on the question asked here-namely, why the Supreme Court has rejected the textualist ideal. She does not claim that this rejection occurred only in reaction to modern lawmaking; she is interested in other ways the Supreme Court modulated its interpretive practices in King. ${ }^{304}$ Still, her discussion provides a useful framework. Analysis of the characteristics of "modern" legislation that she identifies shows that the issues that give

concurring in the judgment) (reforming erroneously drafted statute over protest that the Court cannot "rescue Congress from its drafting errors"); Green v. Bock Laundry Mach. Co., 490 U.S. 504, 509-11, 527 (1989) (correcting an error in a Federal Rule of Evidence); Shaw v. Cooper, 32 U.S. (7 Pet.) 292, 318-19 (1833) (correcting error in the first Patent Act); see also infra note 362 (appellate cases correcting error in the Class Action Fairness Act). Even Justice Scalia approved the result in Green, see Green, 490 U.S. at 527-28 (Scalia, J., concurring in the judgment), and later cited it as a correct application of the doctrine that allows judicial correction of a "scrivener's error," Scalia, supra note 7, at 20. The practice is also straight out of Hart and Sacks. See HART \& SACKs, supra note 285, at 1187-88.

301 Kagan, supra note 8, at min. 20.

302 See, e.g., Gluck, supra note 17 , at 97.

303 Id. at 64, 67, 96-99.

304 See infra notes 308-15 and accompanying text. 
rise to the need to depart from the textualist ideal are not peculiarly modern. They arise from institutional features of the judicial and legislative processes that have always been with us.

Professor Gluck observes that the legislative process has changed in the "modern" period. Although she does not specify a precise date for this period, in another article she draws a contrast between the processes of lawmaking that prevail today and those of the 1970s. ${ }^{305}$ This suggests that the "modern" period to which she refers is more recent than that. Gluck observes that the modern Congress is increasingly prone to passing legislation without following the "textbook process" of lawmaking, which calls for a bill to receive consideration by a committee in each house of Congress and for differences to be resolved by a conference committee after initial passage of the bill in each house. ${ }^{306}$ She also notes the rise in lengthy, omnibus statutes, which may go through multiple committees. ${ }^{307}$

Gluck argues that the changes in the legislative process have implications for statutory interpretation. ${ }^{308}$ She notes, for example, that many canons of construction "make assumptions about Congress that are incompatible with . . . modern legislative complexity." 309 She asserts that the "modern legislative context" makes statutory mistakes "inevitable." 310 She also observes that "no modern court is going to read a thousand-page statute cover-to-cover." 311

In Gluck's view, the Supreme Court's decision in King "is the Court's most explicit recognition ever of modern statutory complexity." 312 The Court, Gluck argues, departed from its usual reluctance to look inside the black box of the legislative process. ${ }^{313}$ Usually, the Court does not vary its interpretive methods based on the process Congress uses to pass a statute, but in King, Gluck suggests, the Court drew "an ACA-specific distinction based on the statute's unusual enactment process." ${ }^{14}$ Gluck suggests that King foreshadows "the next-

305 In Abbe R. Gluck, Anne Joseph O’Connell \& Rosa Po, Unorthodox Lawmaking, Unorthodox Rulemaking, 115 Colum. L. Rev. 1789, 1791-1804 (2015), the authors refer to the "nowtextbook 1970s model," $i d$. at 1794, and note changes in various measures of legislation and rulemaking since the $1970 \mathrm{~s}, i d$. at $1801 \& \mathrm{n} .55,1803-04$.

306 Gluck, supra note 17, at 99; see also Gluck, O'Connell \& Po, supra note 305, at 1794.

307 Gluck, supra note 17, at 97, 99.

308 See id. at 109-10.

309 Id. at 84.

$310 I d$. at 72 .

311 Id. at 62.

312 Id. at 64.

313 See id. at 63, 65; infra note 326 and accompanying text.

314 Gluck, supra note 17, at 98. 
generation agenda for statutory interpretation theory and doctrine," in which the Supreme Court will have to address a "new set of questions" about how courts should adjust their interpretive methods in light of the challenges posed by "modern statutory complexity" and the increased use of unorthodox lawmaking. ${ }^{315}$

It is true that in King the Supreme Court announced that it was adjusting an interpretive rule in light of the process by which Congress enacted the ACA. ${ }^{316}$ The specific point concerned the interpretive canon against statutory surplusage. ${ }^{317}$ This canon normally counsels against construing a statute so that any of its text is duplicative or of no consequence. ${ }^{318}$ The plaintiffs in King argued that interpreting the fateful words "Exchange established by the State" in 26 U.S.C. § 36B to encompass federal exchanges would violate this canon. ${ }^{319}$ Under this interpretation, the plaintiffs argued, words would be surplusage: the limitation of subsidies to insurance purchased on an exchange "established by the State" would have no effect if subsidies were in fact available on both state and federally established exchanges. ${ }^{320}$ Justice Scalia agreed and complained particularly that under this interpretation the words "established by the State" were not merely duplicative of another part of the statute (which would be bad enough), but had "no effect whatever," a result that should be most strongly disfavored. ${ }^{321}$

In response, the Court first noted that the rule against statutory surplusage is only a guide, not an inflexible rule. ${ }^{322}$ But in addition, the Court observed that it specially hesitated to apply the rule to the ACA in light of the Act's enactment process. The Court observed that Congress wrote most of the statute "behind closed doors, rather than through "the traditional legislative process," and that Congress passed much of the Act using the unusual procedure of "reconciliation," which limited debate and amendments and avoided a Senate filibuster. ${ }^{323}$ The result, the Court said, was that "the Act does not reflect the type of care and deliberation that one might expect of such

\footnotetext{
315 Id. at $109-10$.

316 See King v. Burwell, 135 S. Ct. 2480, 2492 (2015).

317 Id.

318 See Scalia \& Garner, supra note 91, at 174.

319 King, 135 S. Ct. at 2492.

320 Id.

321 Id. at 2498 (Scalia, J., dissenting).

$322 I d$. at 2492 (majority opinion).

323 Id. (quoting John Cannan, A Legislative History of the Affordable Care Act: How Legislative Procedure Shapes Legislative History, 105 Law LiB. J. 131, 163 (2013)).
} 
significant legislation," and indeed, the Court noted, the Act contained "more than a few examples of inartful drafting." 324 Therefore, the Court concluded, the statute was not suitable for "rigorous application" of the traditional canon against statutory surplusage, ${ }^{325}$ which is based on an assumption of careful statutory drafting.

Thus, Professor Gluck is correct that in King the Court took the unusual (though not unprecedented) step of explicitly varying its interpretive methods in response to the process Congress used to pass the statute involved. ${ }^{326}$ But the real significance of King lies in what the Court did not change in response to "modern" legislation: its rejection of the textualist ideal. An examination of the attributes of "modern" legislation to which Professor Gluck refers reveals that the Supreme Court's rejection of Justice Scalia's textualist ideal does not arise from the "modern" Congress's legislative processes. It is not peculiarly a product of "unorthodox" lawmaking, and does not apply only in cases of massively long statutes.

The difficulties inherent in the textualist ideal have always been with us. These difficulties apply to statutes old and new, short and long. They apply to statutes that go through the most orthodox legislative processes as well as to those that do not. There is no amount of legislative perspicacity that avoids them. The difficulties with the textualist ideal arise from institutional features of lawmaking and judging that are inherent in the legislative and judicial processes, however those processes are performed. In particular, they arise from the fact that the legislature acts generally and in advance, while the judiciary resolves particular questions at the moment a statute is applied. So long as this remains true, legislatures will inevitably produce statutes which require deviation from the textualist ideal. The Sections below provide examples that illustrate these points.

\section{Interpretive Difficulties Posed by Pre-"Modern" Statutes}

First, it is clear that the difficulties inherent in the textualist ideal are not peculiarly the product of the "modern" legislative process. They have always existed, and the Supreme Court has always re-

324 Id.

325 Id.

326 For other cases where the Court has referenced the sloppiness of the legislative process as a factor in its interpretation of a statute, see United States v. Granderson, 511 U.S. 39, 51-52 (1994), noting that the statutory provision at issue "seems to have been inserted into the Anti-Drug Abuse Act without close inspection," and United States v. Bass, 404 U.S. 336, 344 (1971), noting that the provision "was hastily passed, with little discussion, no hearings, and no report." 
sponded to them. Consider, for example, classic cases such as United States v. Storer Broadcasting and Federal Power Commission v. Texaco, discussed earlier. ${ }^{327}$ As noted above, in each of these cases, the Supreme Court disregarded clear statutory text. But the text was not part of a "modern" (post-1970s) statute-these are venerable cases that deal with venerable statutes. The Supreme Court decided Storer Broadcasting in 1956, over sixty years ago, and the case concerned the Communications Act of 1934. ${ }^{328}$ Texaco was decided in 1964 and concerned problematic language enacted by the Natural Gas Act of $1938 . .^{329}$

Thus, in rejecting the textualist ideal in King, the Supreme Court did not invent any principles of statutory interpretation that were uniquely driven by "modern" legislation. The Court's rejection of the textualist ideal stretches back for decades-indeed, for centuries. In 1868 the Supreme Court considered whether a federal statute making it a crime to obstruct the passage of the mail or any mail carrier applied to a state police officer who arrested a mail carrier for allegedly committing murder. ${ }^{330}$ The statute made no exception for such cases; it provided that "if any person shall knowingly and wilfully [sic] obstruct or retard the passage of the mail, or of any driver or carrier, or of any horse or carriage carrying the same, he shall, upon conviction, for every such offence, pay a fine not exceeding one hundred dollars." The textualist ideal that the text is the law would have required the Court to hold the statute applicable, but the Court rejected that ideal. The Court remarked that "[a]ll laws should receive a sensible construction." 332 Contrary to the textualist ideal, which applies statutory text even when doing so leads to a foolish, unanticipated result, the Court held:

General terms should be so limited in their application as not to lead to injustice, oppression, or an absurd consequence. It will always, therefore, be presumed that the legislature intended exceptions to its language, which would avoid results

327 See supra notes $145-56$ and accompanying text.

328 Communications Act of 1934, Pub. L. No. 73-416, § 309, 48 Stat. 1064, 1085. The statute had been amended and the relevant language changed somewhat by the time the Supreme Court considered it, but the fundamental point that the text commanded the agency to give a hearing to disappointed applicants, was present in the original statute. See United States v. Storer Broad. Co., 351 U.S. 192, 193, 202 (1956).

329 Natural Gas Act, Pub. L. No. 75-688, ch. 556, § 19(b), 52 Stat. 821, 831 (1938); see Fed. Power Comm'n v. Texaco, Inc., 377 U.S. 33, 37 (1964).

330 United States v. Kirby, 74 U.S. (7 Wall.) 482, 483-84 (1868).

331 Id. at 483 (emphasis added).

332 Id. at 486. 
of this character. The reason of the law in such cases should prevail over its letter. ${ }^{333}$

Thus, the problems leading to rejection of the textualist ideal existed long before the modern era.

\section{Interpretive Difficulties Posed by Statutes Adopted Via the "Orthodox" Legislative Process}

Several Supreme Court cases also show that the need to depart from the textualist ideal is not a special product of "unorthodox" lawmaking. The need for sensitive consideration of a statute's purpose applies equally to statutes that go through the traditional lawmaking process. The recent case of Zuni Public School District No. 89 v. Department of Education illustrates this point. ${ }^{334}$ As previously noted, the Court, over Justice Scalia's spirited dissent, found it necessary in that case to give priority to the history and purpose of the statute at issue over the statute's literal language..$^{335}$ But the statute at issue in Zuni was adopted through the "orthodox" legislative process. The language at issue was enacted by the Improving America's Schools Act of 1994, ${ }^{336}$ which was considered by a committee in each house of Congress, with each issuing a report. ${ }^{337}$ The two houses also held a conference and filed a Conference Report. ${ }^{338}$ The congressional database, Congress.gov, shows copious other actions including hearings, floor consideration, and appointment of conferees, demonstrating Congress's lengthy deliberation of the bill. ${ }^{339}$ This illustrates that even the full, traditional legislative process is no safeguard against the adoption of statutory language that might require sensitive judicial interpretation due to a divergence between its literal language and the statutory purpose.

333 Id. at 486-87; see also United States v. Hart, 26 F. Cas. 193, 194 (C.C.D. Pa. 1817) (No. 15,316) (holding that the same statute does not apply where a state officer stops a mail coach that is driving dangerously); $c f$. Ginia Bellafante, A Mailman Handcuffed in Brooklyn, Caught on Video, N.Y. Times (Mar. 25, 2016) (postal carrier arrested by local police).

334 See supra notes 158-67 and accompanying text.

335 See Zuni Pub. Sch. Dist. No. 89 v. Dep’t of Educ., 550 U.S. 81, 93 (2007).

336 Improving America's Schools Act of 1994, Pub. L. No. 103-382, § 8009, 108 Stat. 3518, 3764-65 (codified as amended in scattered sections of 20 U.S.C.); see Zuni, 550 U.S. at 90-91 (noting that Congress passed the provision at issue in 1994).

337 H.R. Rep. No. 103-425 (1994) (pertaining to H.R. 6); S. ReP. No. 103-292 (1994) (pertaining to S. 1513, the companion Senate bill).

338 H.R. REP. No. 103-761 (1994) (Conf. Rep.).

339 See Actions-H.R.6-103rd Congress (1993-1994), Congress.gov, https:// www.congress.gov/bill/103rd-congress/house-bill/6/all-actions [https://perma.cc/37GC-HN5K] (last visited May 12, 2017). 
Similar observations apply to the Communications Act of 1934, which gave rise to the Storer Broadcasting case. The legislative process included a House Report, ${ }^{340}$ a Senate Report, ${ }^{341}$ a Conference Report, ${ }^{342}$ and extensive hearings and floor debates. ${ }^{343}$ Yet, this fully "orthodox" process did not save the statute from requiring a substantial judicial deviation from facially clear statutory text in order to arrive at a sound construction.

Indeed, one further example shows that not only do drafting problems infect statutes that go through the orthodox legislative process, but there is no conceivable legislative process that can prevent the need for judicial interpretation that departs from the textualist ideal. The thoroughness of consideration given to a statute is not a safeguard against statutory drafting error, no matter how solid the process may be. This is the lesson of a problem that arose in the basic federal venue statute, 28 U.S.C. $\S 1391 .{ }^{344}$ Prior to a recent statutory fix, ${ }^{345}$ this statute contained a drafting error, with the result that its text, if taken at face value, could lead to a paradoxical and obviously unintended result. In what was then 28 U.S.C. $§ 1391$ (a)(1), the venue statute permitted a plaintiff to lay venue in "a judicial district where any defendant resides, if all defendants reside in the same State." 346 This language seems simple enough, but because corporate defendants can be deemed to have more than one residence for venue purposes, ${ }^{347}$ the language could have a bizarre effect in a case with multiple defendants, at least one of which is a corporation. If, for example, a case had two defendants, one a corporate defendant which was deemed to reside in both Michigan and Delaware, and the other an individual defendant who resided only in Michigan, then a straightforward reading of $\S 1391$ (a)(1) would compel the conclusion that the plaintiff could lay venue in the federal district of Delaware, because that would be "a judicial district where any defendant resides" in a

340 H.R. REP. No. 73-1850 (1934).

341 S. Rep. No. $73-781$ (1934).

342 H.R. Rep. No. 73-1918 (1934) (Conf. Rep.).

343 See Max D. Paglin, A Legislative History of the Communications Act of 1934 119-342 (1989) (Senate hearings); id. at 343-710 (House hearings), id. at 783-920 (House and Senate floor consideration).

34428 U.S.C. $\$ 1391$ (2012). I previously discussed this example in Jonathan R. Siegel, What Statutory Drafting Errors Teach Us About Statutory Interpretation, 69 Geo. WASH. L. Rev. 309, 311-19 (2001).

345 See Federal Courts Jurisdiction and Venue Clarification Act of 2011, Pub. L. No. 112-63, $\S 202,125$ Stat. 758,763 (amending 28 U.S.C. $§ 1391$ (2006)).

34628 U.S.C. $\S 1391(\mathrm{a})(1)$ (2006).

347 See id. $\S 1391(\mathrm{c})$. 
case in which "all defendants reside in the same State." ${ }^{448}$ This result is paradoxical and unintended, as it would drag the individual defendant all the way from Michigan to Delaware to be sued, despite the obvious intention to permit venue only in a state where all defendants reside. The statutory text that facially permits this result was evidently a drafting error. ${ }^{349}$

However, this drafting error did not result from a careless legislative process. Indeed, "[t]he most ardent proponent of diligence and precision in statutory drafting could not have designed a more thorough and deliberate process than the one by which the language of $\S 1391$ was actually adopted." 350 The problematic language of $\S 1391$ was enacted by the Federal Courts Study Implementation Act of $1990,{ }^{351}$ which, as its title suggests, implemented a study published by the Federal Courts Study Committee. ${ }^{352}$ The Committee was an eminent group that spent more than fifteen months coming up with its recommendations after public notice and hearings. ${ }^{353}$ Moreover, the Committee's recommendation with regard to the language of $\S 1391$ drew on a prior study by the American Law Institute, ${ }^{354}$ which began in 1960, consumed over eight years of work, and involved the publication of six tentative drafts. ${ }^{355}$

This example shows that drafting errors can infect statutes adopted through the most rigorous and orthodox methods. Congress, the Federal Courts Study Committee, and the American Law Institute labored diligently for over thirty years to create the language of

348 Following a statutory fix, the venue statute now avoids this problem by permitting a plaintiff to lay venue in "a judicial district in which any defendant resides, if all defendants are residents of the State in which the district is located." 28 U.S.C. $§ 1391$ (b)(1) (2012). I hope I may be forgiven for pointing out that this fix was prompted by my article discussing the error in this statute. See Am. Law Inst., Federal Judicial Code Revision Project 174-75, 175 n.29 (2004) (citing Siegel, supra note 344, at 312-15).

349 In the only case I was able to find presenting the issue, a district court curtly rejected an argument for applying the text of $\S 1391(a)(1)$ literally. See Dashman v. Peter Letterese \& Assocs., Inc., 999 F. Supp. 553, 554-55 (S.D.N.Y. 1998).

350 Siegel, supra note 344, at 341.

351 Federal Courts Study Committee Implementation Act of 1990, Pub. L. No. 101-650, $\S 311,104$ Stat. 5104, 5114.

352 The Fed. Courts Study Comm., Report of the Federal Courts Study CommitTEE (1990).

353 See id. at 31-33.

354 See id. at 94; see also H.R. ReP. No. 101-734, at 23 (1990).

355 Am. Law Inst., Study of the Division of Jurisdiction Between State and FedERAl Courts xi-xii (1969). 
$\S 1391$, and they still made a mistake. ${ }^{356}$ There is simply no drafting process that can adequately safeguard against all drafting error.

\section{Interpretive Difficulties Posed by Short Statutes}

Finally, difficulties in statutory interpretation are by no means limited to massive statutes that span thousands of pages. For example, the Class Action Fairness Act of 2005 ("CAFA"), 357 as originally passed, contained an egregious drafting error. ${ }^{358}$ CAFA created an exception to the normal principle that a federal district court's order remanding a removed case back to state court is not appealable. ${ }^{359}$ Under CAFA, as originally passed, an order remanding certain class actions back to state court is appealable, provided the court of appeals accepts the appeal as a matter of discretion, and further provided that the appeal meets the following timing rule:

[A] court of appeals may accept an appeal from an order of a district court granting or denying a motion to remand a class action to the State court from which it was removed if application is made to the court of appeals not less than 7 days after entry of the order. ${ }^{360}$

This language is obviously a drafting error. Taking the language as written, it does not set a time limit for appeal of the district court's remand order, it creates a waiting period. That is, a party desiring to appeal the remand order is not required to do so within seven days of the order; rather, the party must wait at least seven days after the order and then appeal. This is contrary to the universal practice under which appeal times for district court orders are stated as a time limit, not as a waiting period. ${ }^{361}$

Although the issue raised by CAFA never reached the Supreme Court, the statutory language was so evidently erroneous that five courts of appeals departed from the language and read it to require the exact opposite of what it literally says. Specifically, the courts required appeals under the statute to be initiated not more than 7 days after the district court's order, rather than not less than 7 days after

356 Siegel, supra note 344, at 342.

357 Class Action Fairness Act (CAFA) of 2005, Pub. L. No. 109-2, 119 Stat. 4 (codified as amended in scattered sections of 28 U.S.C.).

358 CAFA was later fixed to correct the error described here. For detailed discussion of this error, see Siegel, supra note 158, at 137-44.

359 The normal principle is established by 28 U.S.C. $\S 1447$ (d) (2012).

360 CAFA $\S 5,119$ Stat. at 12 (emphasis added).

361 See Siegel, supra note 158, at 138-40 (explaining this point and other reasons why the statutory language is obviously in error). 
the order. ${ }^{362}$ These corrections, however, departed from the textualist ideal. Indeed, some textualist judges were horrified. In a dissent from the denial of rehearing en banc, they accused those who corrected this statutory drafting error of committing an "abuse of our judicial power." 363

The CAFA example is significant in two ways. First, it clearly shows that the textualist ideal is still a minority position in the federal judiciary as a whole. Those who believe in the textualist ideal-who believe that statutory text simply is the law by virtue of being legislatively adopted, regardless of what anyone intended and regardless of whether the text makes good policy sense-would have had to vote to enforce the text of CAFA as written. ${ }^{364}$ Yet none of the numerous courts of appeals that considered the issue did that. ${ }^{365}$

Second, the CAFA example shows that the kind of interpretive difficulty that requires departure from the textualist ideal is not limited to long statutes. The CAFA interpretive dispute did not arise from a massive, thousand-page statute. CAFA occupies just eleven pages in the Statutes at Large. ${ }^{366}$ A court could comfortably read the whole thing-over lunch. So could anyone working on the statute during its passage. The drafting error is there for anyone to notice, yet no one did notice it throughout the congressional consideration of the bill (or at least, if anyone did notice it, it wasn't fixed). Drafting errors that give rise to interpretive difficulties can arise in statutes of any length. ${ }^{367}$

362 Estate of Pew v. Cardarelli, 527 F.3d 25, $27-28$ (2d Cir. 2008); Morgan v. Gay, 466 F.3d 276, 279 (3d Cir. 2006); Miedema v. Maytag Corp., 450 F.3d 1322, 1326 (11th Cir. 2006); Amalgamated Transit Union Local 1309 v. Laidlaw Transit Servs., Inc., 435 F.3d 1140, 1146 (9th Cir.), reh'g denied, 448 F.3d 1092 (9th Cir. 2006); Pritchett v. Office Depot, Inc., 420 F.3d 1090, 1093 n.2 (10th Cir. 2005); see also Spivey v. Vertrue, Inc., 528 F.3d 982, 983-85 (7th Cir. 2008) (taking a slightly different approach that allows appeals within seven days but does not reject appeals after seven days).

363 Amalgamated Transit Union, 448 F.3d at 1095 (Bybee, J., dissenting).

364 See supra note 362. It is not even clear that textualists could have escaped this interpretation by invoking the "absurd results" exception. The requirement to wait seven days before appealing, while certainly out of keeping with appellate practice, is not absurd; there are other situations in which the law provides a waiting period before action can be taken. See Amalgamated Transit Union, 448 F.3d at 1098-99 (Bybee, J., dissenting). The absurd results exception is, in any event, logically inconsistent with the textualist ideal. See Siegel, supra note 158, at 145-53.

365 See supra note 362.

366 See CAFA of 2005, Pub. L. No. 109-2, 119 Stat. 4.

367 In fairness, although CAFA is not lengthy, the process by which it was adopted was in at least one respect unorthodox: the Senate Report on CAFA was not submitted until after the bill had already become law. See Amalgamated Transit Union, 448 F.3d at 1096 (Bybee, J., dissenting). Although CAFA shows that even a short law can give rise to interpretive difficulties, it 


\section{The True Source of the Problem}

As the examples in this Section show, the difficulties with the textualist ideal are not limited to cases involving massive, modern statutes adopted through an unorthodox lawmaking process. They are, rather, inherent in institutional features of the legislative and judicial processes. The critical features of these processes are that the legislature acts generally and in advance, whereas the judiciary resolves particular questions at the moment a statute is applied. ${ }^{368}$ These institutional features, deeply embedded in the very nature of courts and legislatures, guarantee that legislatures will pass statutes that will require courts to deviate from the textualist ideal to reach sound results. ${ }^{369}$

Because the legislature acts generally and in advance, it must inevitably fall prey to problems that give rise to interpretive difficulties. Two such problems account for a substantial portion of them. The first is the problem of generality. The legislature, acting in advance, can never anticipate every situation to which its statutes will apply, and it therefore writes general language that covers some situations that legislators would probably not wish to cover if these situations had occurred to them. ${ }^{370}$ The second problem is simple statutory drafting error, ${ }^{371}$ such as occurred in the CAFA example discussed above. Because the legislature acts generally and in advance, it can never catch every drafting error in its work product.

The legislature does its best to avoid these and similar problems. Under the traditional, "orthodox" process of legislation, Congress refers its draft bills to committees, holds hearings, deploys the expertise of its innumerable staff, exposes its drafts to public scrutiny (thus drawing on the wisdom of crowds), and so forth. ${ }^{372}$ But as the above examples show, these processes are not, and have never been, a com-

could also be claimed as an example of how unorthodox lawmaking causes interpretive problems.

368 See Jonathan R. Siegel, Judicial Interpretation in the Cost-Benefit Crucible, 92 Minn. L. REv. 387, 420 (2007); Siegel, supra note 344, at 341-43.

369 See Siegel, supra note 368, at 420-21.

370 See John F. Manning, The Absurdity Doctrine, 116 Harv. L. Rev. 2387, 2459 (2003) ("[A]bsurdity arises from the problem of statutory generality . ..."). This problem arose, for example, when Congress commanded the FCC to set every rejected license application for a hearing, overlooking the possibility that in some cases there might be nothing to have a hearing about. See supra notes 145-53 and accompanying text.

371 See Siegel, supra note 158, at 137-38; Siegel, supra note 344, at 317.

372 See supra note 306 and accompanying text. 
plete safeguard against drafting error and unanticipated complications.

The judicial process, however, is different. Its institutional features give it a comparative advantage with regard to these interpretive difficulties. The judicial power comes into play once a statute is actually applied. ${ }^{373}$ If statutory text contains a drafting error, the judiciary can focus on it in a case covering the particular point. If an unanticipated situation arises in which applying the statute as written would be absurd, the courts can face that situation. Because the courts decide particular cases that arise in the application of a statute, they can see the problems caused by particular statutory language in a way that legislatures cannot, for the simple reason that the legislature cannot anticipate every problem. ${ }^{374}$

Textualists, including Justice Scalia, have long argued that the institutional limitations of legislatures are no excuse for bad drafting, and, indeed, they have touted their methods as a spur with which to improve the legislative process. ${ }^{375}$ If courts exercise the power to deviate from statutory text in order to rescue Congress from its drafting errors, the textualists say, they will only encourage Congress to be even sloppier the next time around. ${ }^{376}$ Textualists claim that a firm insistence on following statutory text "fosters [the] democratic process" 377 and encourages the kind of careful drafting in which Congress should engage. ${ }^{378}$ If the members of Congress cannot themselves ferret out errors, they should hire staff who can. ${ }^{379}$

The examples discussed in this Section, however, show the textualists' dream of perfecting statutory drafting to be the chimera that it is. There is no process that can successfully anticipate every detail and wring every error out of a statute. If the American Law Institute and the Federal Courts Study Committee, laboring diligently, with public input, for over thirty years, can miss a stunning error in a simple section of the proposed venue statute, Congress cannot hope to do better.

Thus, the need to reject the textualist ideal is inherent in the nature of the legislative and judicial processes. One could imagine a to-

\footnotetext{
373 See Siegel, supra note 368 , at 420.

374 Id.

375 E.g., SCALIA \& GARNER, supra note 91, at 179 ("[E]ncouraging courts to ignore sloppily inserted words results in legislative free-riding and increasingly slipshod drafting.").

376 See id.

377 United States v. Taylor, 487 U.S. 326, 346 (1988) (Scalia, J., concurring in part).

378 See Scalia \& Garner, supra note 91, at 179.

379 Id.
} 
tally different system. If, for example, the legislative and judicial powers were merged in a single body, that body could alter statutory text as needed in the course of deciding a case that called attention to textual difficulties. In such a system, there might be no need to depart from rigid textualism in interpreting statutes. But so long as the legislative and judicial powers remain separated, the legislature acts generally and in advance, and the judiciary acts with respect to particular cases that arise after a statute's passage, sound judicial interpretation will require rejection of the textualist ideal.

The problem is, therefore, not peculiarly modern. It has been with us always. It arises not from modern, unorthodox legislative processes, but from the fact that, as H.L.A. Hart observed, legislators are human beings, not gods. ${ }^{380}$ Professor Gluck says that "statutory mistakes are inevitable in the modern legislative context," 381 but she might equally well have omitted the word "modern." The problem is the same one noted by Aristotle thousands of years ago, when he observed that "in a situation in which the law speaks universally, but the case at issue happens to fall outside the universal formula, it is correct to rectify the shortcoming, in other words, the omission and mistake of the lawgiver due to the generality of his statement." ${ }^{382}$ In sum, the need to reject the textualist ideal is inherent in the nature of the legislative process.

\section{Statutory Interpretation and the Constitution}

As noted earlier, some commentators suggest that the Supreme Court's decision in King "overthrow[s] the Constitution." 383 Justice Scalia and others have asserted to varying degrees that textualism is not only the best method of statutory interpretation, but that it is constitutionally required. ${ }^{384}$ Certainly, if the Constitution demanded that

380 H.L.A. Hart, The Concept of Law 128 (2d ed. 1994).

381 Gluck, supra note 17 , at 72.

382 Aristotle, Nicomachean Ethics 142 (Martin Ostwald trans., The Liberal Arts Press, Inc. 1962). Aristotle thus rejected the textualist ideal and instead believed that "[s]uch a rectification corresponds to what the lawgiver himself would have said if he were present, and what he would have enacted if he had known (of this particular case)." Id.

383 Will, supra note 13.

384 See Scalia, supra note 7, at 35 (stating that if the houses of Congress desire legislative history to have authoritative force, that desire is unconstitutional); John F. Manning, Response, Deriving Rules of Statutory Interpretation from the Constitution, 101 Colum. L. REv. 1648, 1649-51 (2001) (arguing that our constitutional structure compels courts to adopt the "faithful agent" model of statutory interpretation and to reject the English practice of equitable interpretation); Manning, supra note 101, at 706-07 (arguing that the constitutional rule against congressional self-aggrandizement prohibits reliance on legislative history in statutory interpretation). 
courts adopt the textualist ideal, the practical virtues of other interpretive methods would be irrelevant. Courts would be obliged to implement the Constitution.

However, the Constitution does not require courts to adopt the textualist ideal. ${ }^{385}$ The "judicial Power" that the Constitution vests in the courts ${ }^{386}$ permits other methods of statutory interpretation. This can be seen both by examining the original understanding of proper interpretive methods at the time of the Constitution's framing and by looking at common interpretive techniques that courts have in fact used throughout the nation's history.

The Constitution does not specify techniques for statutory interpretation. The Constitution vests the "legislative Power" in Congress, ${ }^{387}$ and in our system of separated powers this means that the courts cannot exercise that power. ${ }^{388}$ But the Constitution vests courts with the "judicial Power." 389 In giving the courts this power, the Framers and ratifiers of the Constitution must have understood that they were giving courts power to act as courts had traditionally acted in matters of statutory interpretation. At the time of the framing, this power would have been understood to encompass nontextualist interpretive techniques.

The Framers intended the practices of the English courts at Westminster to serve as referents for the scope of the judicial power. ${ }^{390}$ These courts, at the time of the framing, used nontextualist techniques in statutory interpretation. ${ }^{391}$ As early as the sixteenth century, in the notable case of Eyston v. Studd, ${ }^{392}$ the court of King's Bench "took it that the ... intent of statutes is more to be regarded and pursued than the precise letter of them." ${ }^{393}$ Similarly, in its famous decision in Hey-

385 For prior analysis on this topic, see Eskridge, supra note 103, at 1099-1105; Eskridge, supra note 70, at 1522-23; William N. Eskridge, Jr., Dynamic Statutory Interpretation, 135 U. PA. L. REv. 1479, 1498-1511 (1987); Siegel, supra note 105, at 1094-98; Cass R. Sunstein, Interpreting Statutes in the Regulatory State, 103 HARv. L. REv. 407, 437-41 (1989).

386 U.S. CONST. art. III, § 1.

387 U.S. ConsT. art. I, $\S 1$.

388 E.g., Plaut v. Spendthrift Farm, Inc., 514 U.S. 211, 224 (1995); Wayman v. Southard, 23 U.S. (10 Wheat.) 1, 42-43 (1825).

389 U.S. CONST. art. III, $\S 1$.

390 E.g., Vt. Agency of Nat. Res. v. United States ex rel. Stevens, 529 U.S. 765, 774 (2000); see also FEC v. Akins, 524 U.S. 11, 24 (1998).

391 See Eyston v. Studd (1574) 75 Eng. Rep. 688, 694; 2 Pl. Com. 459, 464 (establishing nontextualist technique in statutory interpretation as English court precedent); see also Heydon's Case (1584) 76 Eng. Rep. 637, 638; 3 Co. Rep. 7 a, 7 b.

392 (1574) 75 Eng. Rep. 688; 2 Pl. Com. 459.

393 Id. at $694 ; 2 \mathrm{Pl}$. Com. at 464. 
don's Case, ${ }^{394}$ the Exchequer said that "for the sure and true . . . interpretation of all statutes," a court needed to examine four things: the common law before the statute, "the mischief and defect for which the common law did not provide," the remedy that Parliament had provided, and "[t]he true reason of the remedy."395 Having examined these points, the court said, "the office of all the Judges is always to make such ... construction as shall suppress the mischief, and advance the remedy."396

Thus, English statutory interpretation was far from textualist. Plowden, the reporter of Eyston v. Studd, remarked:

[T]he sages of the law heretofore have construed statutes quite contrary to the letter in some appearance, and those statutes which comprehend all things in the letter, they have expounded to extend but to some things, and those which generally prohibit all people from doing such an act, they have interpreted to permit some people to do it, and those which include every person in the letter they have adjudged to reach to some persons only, which expositions have always been founded upon the intent of the Legislature . . . .397

English statutory interpretation became more textualist as time went on, ${ }^{398}$ but at the time of the framing of our Constitution, Plowden's assessment was still hornbook law. ${ }^{399}$

394 (1584) 76 Eng. Rep. 637; 3 Co. Rep. 7 a, 7 b.

395 Id. at 638; 3 Co. Rep. at 7 b.

396 Id.

397 Stradling v. Morgan (1560) 75 Eng. Rep. 305, 315; 1 Pl. Com. 199, 205.

398 See, e.g., Vacher \& Sons, Ltd. v. London Soc'y of Compositors [1913] AC 107 (HL) 121 (appeal taken from Eng.) ("If the language of a statute be plain, admitting of only one meaning, the Legislature must be taken to have meant and intended what it has plainly expressed, and whatever it has in clear terms enacted must be enforced though it should lead to absurd or mischievous results."). More recently, however, the highest British court approved consulting legislative history in statutory interpretation. Pepper v. Hart [1992] 3 WLR 1032 (HL) 1033 (appeal taken from Eng.).

399 E.g., 4 Matthew Bacon, A New Abridgment of the Law 647-48 (2d ed. 1759) ("Such a Construction ought to be put upon a Statute, as may best answer that Intent which the Makers of it had in View . . . Every Thing, which is within the Intent of the Makers of a Statute, is, although it be not within the Letter, as strongly within the Act as that which is within the Intent and the Letter also. . . On the other Hand, a thing, which is within the Letter of an Act of Parliament, is not within the Act, if it is not within the Intention of the Makers of such Act."); see also Hawkins v. Gathercole (1855) 43 Eng. Rep. 1129, 1135-36; 6 De G. M. \& G. 1, 20-21 ("[I]n construing Acts of Parliament, the words which are used are not alone to be regarded. Regard must also be had to the intent and meaning of the Legislature."). 
Blackstone, similarly, approved nontextualist interpretive techniques. He endorsed the principles of Heydon's Case. ${ }^{400} \mathrm{He}$ approved of judicial departure from statutory text in some cases ${ }^{401}$ and not only when the literal language of statutory text had either no meaning or an absurd meaning (as some modern textualists, including Justice Scalia, would allow) ${ }^{402}$ but also in some other cases. Although he recognized that Parliament could, by express language, enact an unreasonable result, he said:

[W]here some collateral matter arises out of the general words, and happens to be unreasonable; there the judges are in decency to conclude that this consequence was not foreseen by the parliament, and therefore they are at liberty to expound the statute by equity, and only quoad hoc disregard it. 403

Thus, for example, Blackstone said that if Parliament by statute provided that a man could try all cases that arose within his manor, a court should interpret the statute to mean that the man could not try cases to which he was a party, because even though such a case would fall within the language of the statute, "it is unreasonable that any man should determine his own quarrel." 404

Thus, the Framers of our Constitution, based on the common understanding of their time, would have known that by vesting the courts with the "judicial Power," 405 they were authorizing nontextualist techniques of statutory interpretation. To be sure, they would have understood that the judicial role in statutory interpretation is circumscribed and is not comparable to the power of the legislature to make policy decisions by statute. But they would not have believed that courts were bound to follow statutory text slavishly because " $[\mathrm{t}] \mathrm{he}$ text is the law." ${ }^{406}$

This original understanding is confirmed by actual judicial practices. Courts have used nontextualist interpretation since the founding of the nation. For an early example, consider United States $v$. Palmer. ${ }^{407}$ The case concerned a federal piracy statute. The statute

400 See William Blackstone, Commentaries on the Laws of England 87 (Univ. of Chicago Press 1979).

401 See Siegel, supra note 105, at 1095-96.

402 Blackstone, supra note 400, at 60; see Scalia, supra note 7, at 20-21.

403 BLACKSTONE, supra note 400, at 91.

404 Id.

405 U.S. Const. art. III, § 1.

406 Scalia, supra note 7, at 22.

40716 U.S. (3 Wheat.) 610 (1818). 
provided "[t]hat if any person or persons commit upon the high seas ... murder or robbery, . . . every such offender shall be deemed ... a pirate and a felon, and being thereof convicted, shall suffer death." ${ }_{408}$ The case presented the question whether the statute covered a piracy committed on the high seas by a non-U.S. citizen against a non-U.S. ship and non-U.S. victims. ${ }^{409}$ The Court, speaking through Chief Justice Marshall, recognized that "[t]he words of the section are in terms of unlimited extent." ${ }_{10}$ The statutory text "any person or persons," was, the Court acknowledged, "broad enough to comprehend every human being." ${ }^{111}$ Moreover, the text did not require a strained interpretation to avoid constitutional concern. The Court said that there could be "no doubt" of the power of Congress to punish all piracy, even in cases where neither the pirate, nor the ship, nor the victims have a connection to the United States. ${ }^{412}$ Nonetheless, the Court held that the statute did not cover such cases. ${ }^{413}$ The Court said that "general words must not only be limited to cases within the jurisdiction of the state, but also to those objects to which the legislature intended to apply them." ${ }^{14}$ The Court concluded that Congress did not intend the statute to cover piracies having no connection with the United States. ${ }^{415}$

The Court continued to depart from the textualist ideal as the decades went by. In Brown v. Duchesne, ${ }^{416}$ for example, the plaintiff sued for infringement of a patent, allegedly violated by the use of the patented invention on a foreign ship during a single visit to a U.S. port. ${ }^{417}$ The Court acknowledged that " $[\mathrm{t}]$ he general words used in the clause of the patent laws granting the exclusive right to the patentee to use the improvement, taken by themselves, and literally construed, without regard to the object in view, would seem to sanction the claim of the plaintiff." 418 But, the Court said:

[T]his mode of expounding a statute has never been adopted by any enlightened tribunal-because it is evident that in many cases it would defeat the object which the Legislature

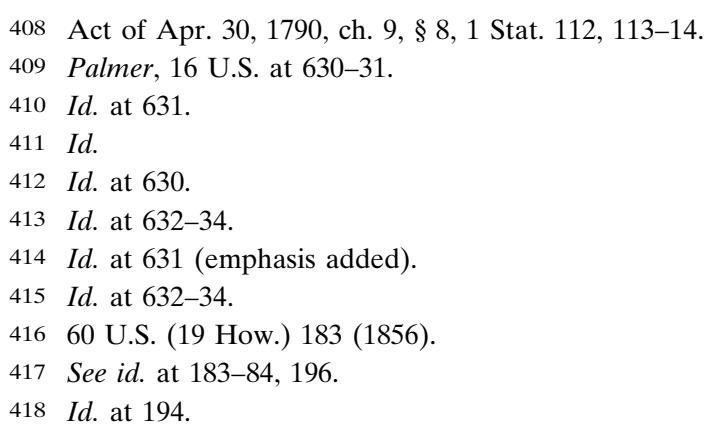


intended to accomplish. And it is well settled that, in interpreting a statute, the court will not look merely to a particular clause in which general words may be used, but will take in connection with it the whole statute (or statutes on the same subject) and the objects and policy of the law, as indicated by its various provisions, and give to it such a construction as will carry into execution the will of the Legislature, as thus ascertained, according to its true intent and meaning. ${ }^{419}$

Similarly, as noted earlier, in 1869 the Court read an unwritten restriction into a federal law, justifying its gloss on the ground that "[a]11 laws should receive a sensible construction." ${ }^{420}$ In the same case, the Court said that "[g]eneral terms should be so limited in their application as not to lead to injustice, oppression, or an absurd consequence.... The reason of the law in such cases should prevail over its letter." $" 21$

Thus, judicial departure from the textualist ideal has long been a common practice. Moreover, as the cases discussed earlier show, such departures have remained common to the present day. Despite the hullabaloo surrounding King, the case made no sharp break with prior practice. As Yates showed, the Court's decision in King did not invent special interpretive principles to get to a desired result in a big case; it merely did what the Supreme Court does routinely.

To be sure, one can also cite cases, both early and recent, that take a more textualist approach. Some early cases, while referring to the concept of legislative intent, say that "this intention is to be searched for in the words which the legislature has employed to convey it." ${ }^{222}$ More recently, when the Court desires to eschew nontextualist methods, it says: "When the words of a statute are unambiguous, then . . . judicial inquiry is complete." "423 But the cases discussed herein show that the Court has never adopted these principles as a

$419 I d$.

420 United States v. Kirby, 74 U.S. (7 Wall.) 482, 486 (1869).

421 Id. at 486-87. For another venerable example, see Murdock v. City of Memphis, 87 U.S. (20 Wall.) 590 (1875).

422 Schooner Paulina's Cargo v. United States, 11 U.S. (7 Cranch) 52, 60 (1812) (Marshall, C.J.) (quoted in John F. Manning, Textualism and the Equity of the Statute, 101 Colum. L. REv. 1,91 (2001)).

423 Conn. Nat'l Bank v. Germain, 503 U.S. 249, 254 (1992) (quoting Rubin v. United States, 449 U.S. 424, 430 (1981)); see also, e.g., Nichols v. United States, 136 S. Ct. 1113, 1119 (2016) ("[E]ven the most formidable argument concerning the statute's purposes could not overcome the clarity we find in the statute's text." (quoting Kloeckner v. Solis, 133 S. Ct. 596, 607 n.4 (2012))). 
firm rule. ${ }^{424}$ The Court recites textualist slogans when it agrees with the textualist result in a particular case, but the point of the textualist ideal is to stick with the text even when likely intent and policy cuts the other way. In cases where these other influences are strong enough, the Court shows that it has never truly embraced the textualist ideal.

The longstanding judicial use of interpretive techniques that depart from the textualist ideal supports the original understanding, which is that such techniques do not overthrow the Constitution. Rather, "[t]o construe statutes so as to avoid absurd or glaringly unjust results, foreign to the legislative purpose, is . . . a traditional and appropriate function of the courts." 425

\section{The Future of the Textualist Ideal}

As this Article has suggested, Justice Scalia's decades-long effort to promote textualism had considerable influence on the Supreme Court's interpretive methods, but fell short of convincing the Court to adopt the textualist ideal. With Justice Scalia gone, what will become of the textualist ideal? The Court's increased focus on statutory text is not likely to change soon, but the textualist ideal seems likely to recede in influence.

Now that Justice Scalia is no longer on the Supreme Court, it is difficult to identify any Justice who will likely play a similar role in crusading for the textualist ideal. Certainly none of the more liberal Justices are consistent textualists. They all joined the majority in King, over Justice Scalia's fiery textualist dissent. ${ }^{426}$ Some of the more liberal Justices occasionally play the textualist role-Justice Kagan, for example, considers herself a textualist, and indeed she wrote the textualist dissent in Yates ${ }^{427}$-but none of them embrace Justice Scalia's textualist ideal.

Perhaps somewhat more surprisingly, the Court's more conservative Justices also seem unlikely to carry on Justice Scalia's textualist campaign. Chief Justice Roberts, of course, wrote the Court's opinion

424 Actually, as I have previously shown, the Court generally does not give real precedential effect to any methodological pronouncements in statutory interpretation cases. See Jonathan R. Siegel, The Polymorphic Principle and the Judicial Role in Statutory Interpretation, 84 Tex. L. REv. 339, 385-89 (2005). "[W]hen the Court issues opinions interpreting statutes, stare decisis effect attaches to the ultimate holding as to the meaning of the particular statute interpreted, but not to general methodological pronouncements, no matter how apparently firm." Id. at 389 .

425 Sorrells v. United States, 287 U.S. 435, 450 (1932).

426 See King v. Burwell, 135 S. Ct. 2480, 2484 (2015).

427 See Yates v. United States, 135 S. Ct. 1074, 1090-1101 (2015) (Kagan, J., dissenting). 
in King ${ }^{428}$ and he also was part of the Yates plurality. ${ }^{429}$ So he is comfortable with methods that depart from the textualist ideal.

Justice Kennedy frequently espouses textualist views. In cases where he agrees with the textualist result, he will say: "It is well established that 'when the statute's language is plain, the sole function of the courts - at least where the disposition required by the text is not absurd-is to enforce it according to its terms." ${ }^{430}$ Similarly, he takes a harsh line with regard to the ability of courts to depart from statutory text on the grounds that the text produces an absurd result. $\mathrm{He}$ says that the "absurd results" exception must be limited "to situations where the result of applying the plain language would be, in a genuine sense, absurd, i.e., where it is quite impossible that Congress could have intended the result, and where the alleged absurdity is so clear as to be obvious to most anyone." ${ }^{431}$

Nonetheless, Justice Kennedy, like Chief Justice Roberts, joined the Supreme Court majority in King. ${ }^{432} \mathrm{He}$ also cast his vote with the nontextualist majority in Zuni, discussed earlier. ${ }^{433} \mathrm{He}$ is not a consistent textualist in the Scalia mold. The same is true of Justice Alito. Although Justice Alito joined Justice Scalia's dissent in King, ${ }^{434}$ he voted with the majority in Zuni ${ }^{435}$ he concurred in Yates, ${ }^{436}$ and he has joined other nontextualist opinions as well. ${ }^{437}$ Justice Alito is not a textualist.

Thus, of all the remaining Justices, only Justice Thomas is a plausible candidate for picking up Justice Scalia's fallen textualist mantle. Justice Thomas usually joined Justice Scalia's textualist opinions, even when no other Justice did. Moreover, some of the opinions he joined suggest a real commitment to textualism.

428 See King, 135 S. Ct. at 2485.

429 See Yates, 135 S. Ct. at 1078.

430 Lamie v. U.S. Tr., 540 U.S. 526, 534 (2004) (Kennedy, J.) (quoting Hartford Underwriters Ins. Co. v. Union Planters Bank, N.A., 530 U.S. 1, 6 (2000)).

431 Pub. Citizen v. U.S. Dep't of Justice, 491 U.S. 440, 470-71 (1989) (Kennedy, J., concurring in the judgment) (citation omitted).

432 King, 135 S. Ct. at 2484.

433 Zuni Pub. Sch. Dist. No. 89 v. Dep't of Educ., 550 U.S. 81, 83 (2007).

434 King, 135 S. Ct. at 2496 (Scalia, J., dissenting).

435 Zuni, 550 U.S. at 83.

436 Yates v. United States, 135 S. Ct. 1074, 1089 (2015) (Alito, J., concurring in the judgment).

437 See, e.g., Limtiaco v. Camacho, 549 U.S. 483, 492 (2007) (Souter, J., concurring in part and dissenting in part). For a discussion of why this is a nontextualist opinion, see Siegel, supra note 158 , at $157-61$. 
A vivid illustration of Justice Thomas's agreement with Justice Scalia occurred, for example, with regard to the statutory prohibition against "second or successive habeas corpus" petitions, ${ }^{438}$ which poses a sharp divergence between statutory text and likely legislative intent. Prior to the 1996 Antiterrorism and Effective Death Penalty Act ("AEDPA"), ${ }^{439}$ judicial practice permitted state prisoners to seek habeas relief multiple times and even permitted them under some circumstances to seek habeas relief on the same ground multiple times. ${ }^{440}$ With AEDPA, Congress put an end to this practice. Since 1996, the habeas statute has provided that "[a] claim presented in a second or successive habeas corpus application under section 2254 that was presented in a prior application shall be dismissed." 441

A question arose, however, concerning habeas petitions that are initially dismissed on technical grounds, such as that the petitioner had failed to exhaust his state remedies, without reaching the merits of the petitioner's challenge to his state conviction. Can such a prisoner, after curing the technical defects in the petition, raise the same claims in another habeas petition? The Supreme Court, employing purposive reasoning, said that the answer was yes. ${ }^{442}$ The Court was evidently moved by the consideration that the purpose of the new statute was to prevent prisoners from getting consideration of the merits of a habeas petition multiple times. ${ }^{443}$ Therefore, the Court held, notwithstanding the statutory text, that the bar against second or successive petitions should not apply where the prisoner did not previously receive an adjudication of the merits of his claim. 444 The Court noted that a contrary ruling would have far-reaching and "seemingly perverse"

43828 U.S.C. $\$ 2244($ b)(1) (2012).

439 Antiterrorism and Effective Death Penalty Act (AEDPA) of 1996, Pub. L. No. 104-132, 110 Stat. 1214.

440 See, e.g., Sanders v. United States, 373 U.S. 1, 15-19 (1963) (permitting multiple habeas petitions provided that a prisoner does not "abuse" the writ). Even before AEDPA, the Supreme Court judicially tightened the standards for permitting prisoners to claim habeas on the same ground multiple times, but did not forbid it altogether. See McCleskey v. Zant, 499 U.S. 467, 489-96 (1991).

44128 U.S.C. $\$ 2244$ (b)(1). The statute also strictly limits a prisoner's ability to raise, in a second or successive habeas petition, a claim for relief that was not presented in a previous petition. See id. §2244(b)(2).

442 Stewart v. Martinez-Villareal, 523 U.S. 637, 644-46 (1998).

443 See id. at 643-46.

444 Id. at $645-46$. 
implications. ${ }^{445}$ Seven Justices joined the Court's opinion, which was written by Chief Justice Rehnquist. ${ }^{446}$

Justice Scalia, joined by Justice Thomas, dissented. He said that the Court's opinion "flouts the unmistakable language of the statute." ${ }^{447}$ Adhering strictly to the statutory text, Justice Scalia was prepared to say that a state prisoner who sought habeas relief prematurely lost the right to receive even one consideration of the merits of his claim. ${ }^{448}$ Justice Thomas joined this opinion, ${ }^{449}$ and he voted with Justice Scalia in other cases discussed in this Article. ${ }^{450}$

So of the remaining Justices, Justice Thomas is the one who at least might have an interest in carrying on Justice Scalia's textualist campaign. But Justice Thomas's opinions, although generally following the textualist line, lack the level of textualist conviction that Justice Scalia brought to the interpretive enterprise. $451 \mathrm{He}$ joined opinions embodying Justice Scalia's fiery textualism ${ }^{452}$ but he did not write such opinions himself. He did not take care, as Justice Scalia did, to disassociate himself from any reliance on legislative history in opinions that he otherwise joined. ${ }^{453}$ It seems unlikely that Justice Thomas will carry on a campaign for textualism with anything like Justice Scalia's fervor.

Bereft of its great champion, the textualist ideal seems likely to recede in importance. To be sure, it will not likely fade away alto-

445 Id. at 644. The Court observed that such a rule "would mean that a dismissal of a first habeas petition for technical procedural reasons would bar the prisoner from ever obtaining federal habeas review." Id. at 645.

446 Id. at 638; see also Slack v. McDaniel, 529 U.S. 473, 478, 487 (2000) (holding that a petition filed after an initial petition was denied on procedural grounds "is not a second or successive petition").

447 Martinez-Villareal, 523 U.S. at 646 (Scalia, J., dissenting).

448 See id.

449 Id. Of course, one could argue that this case illustrates Justice Thomas's distaste for habeas corpus more than his commitment to textualism.

450 King v. Burwell, 135 S. Ct. 2480, 2496 (2015) (Scalia, J., dissenting); Yates v. United States, 135 S. Ct. 1074, 1090 (2015) (Kagan, J., dissenting) (both Justices Scalia and Thomas joined Justice Kagan's dissent); Zuni Pub. Sch. Dist. No. 89 v. Dep’t of Educ., 550 U.S. 81, 108 (2007) (Scalia, J., dissenting); Limtiaco v. Camacho, 549 U.S. 483, 484 (2007) (Justice Scalia joined Justice Thomas's opinion for the Court).

451 See supra Section I.A.

452 See, e.g., King, 135 S. Ct. at 2501 (Scalia, J., dissenting) ("Pure applesauce.").

453 See, e.g., Octane Fitness, LLC v. ICON Health \& Fitness, Inc., 134 S. Ct. 1749, 1752, 1753 nn.1-3 (2014) (Justice Scalia joined the Court's opinion except for certain parts which relied on legislative history, whereas Justice Thomas joined the entire opinion); Doe v. Chao, 540 U.S. 614, 616, 622-23, 623 nn.7-8 (2004) (same); Nat'l Credit Union Admin. v. First Nat'l Bank \& Tr. Co., 522 U.S. 479, 482, 493 n.6 (1998) (Justice Scalia joined all but a single footnote of the Court's opinion, which relied on legislative history; Justice Thomas wrote the opinion). 
gether. As noted earlier, Justice Scalia had great success in moving the Supreme Court in a more textualist direction. ${ }^{454} \mathrm{He}$ successfully recalled everyone's attention to the importance of statutory text. ${ }^{455}$ In doing so, he performed a useful public service. Before his elevation to the Supreme Court, statutory interpretation had gotten somewhat out of hand. It is wrong to give legislative history the same weight as statutory text, and Justice Scalia usefully pointed this out. 456 It is important to remember that statutes do not pursue their main purposes at all costs, and Justice Scalia made this point as well. ${ }^{457}$ His forceful articulation of textualism created sufficient appreciation for the importance of statutory text that it seems unlikely that interpretive methods will slide all the way back to the excesses of the 1960s and 1970s, at least anytime soon.

But at the same time, it is important to recognize that even decades of sustained effort by an ardent, forceful champion was insufficient to convince the Supreme Court to adopt the textualist ideal. At most, Justice Scalia was able to bring one other Justice over to his cause. ${ }^{458}$ The textualist ideal remains a minority position, not only on the Supreme Court, but in the federal judiciary as a whole, ${ }^{459}$ as well as in the legal academy. ${ }^{460}$

Thus, the textualist ideal could not win over the judiciary even with a highly influential and articulate Justice constantly espousing its cause. Given that the Supreme Court steadfastly declined to abjure reliance on legislative history despite the constant irritant of Justice Scalia's refusal to join so much as a footnote that cited it, it seems unlikely that the Court will give up on legislative history now that no

454 See Eskridge, supra note 25, at 656 ("In each year that Justice Scalia has sat on the Court, however, his theory has exerted greater influence on the Court's practice."); supra Section I.B.

455 See Eskridge, supra note 25, at 656 (explaining that due to Justice Scalia, "the Court has been increasingly influenced by textual and procedural canons of statutory interpretation"); supra Section I.B.

456 See Eskridge, supra note 70, at 1511 (“[A] statutory text's apparent plain meaning must be the alpha and the omega in a judge's interpretation of the statute."); supra Section I.A.

457 Am. Express Co. v. Italian Colors Rest., 133 S. Ct. 2304, 2309 (2013) (Scalia, J.) (quoting Rodriguez v. United States, 480 U.S. 522, 525-26 (1987) (per curiam)); see supra Section II.B.

458 See supra note 450 and accompanying text.

459 See, e.g., supra note 362 (cases showing that six out of six circuits that interpreted CAFA refused to read it textually).

460 See, e.g., Eskridge, supra note 70, at 1513; Edward L. Rubin, Statutory Interpretations and the Therapy of the Obvious, 68 VAND. L. REv. 159, 160 (2015) (book review) ("Scalia has failed to persuade a majority of Supreme Court Justices, judges in general, or scholarly observers . . ."); supra note 103. 
one will protest each time against its supposed illegitimacy. Similarly, if the Supreme Court would not embrace the principle that the text is the law with Justice Scalia continually pressing for it, it seems unlikely to embrace that principle without him.

Justice Scalia's death mutes the most prominent voice agitating for the textualist ideal. There is no comparable champion of such articulateness or in such a prominent position. It seems likely that Justice Scalia's death ends the chances of ultimate victory for the late Justice's textualist ideal.

\section{CONClusion}

In rejecting the textualist ideal in King, the Supreme Court was appropriately cautious. The Court did not approve freewheeling purposivist interpretation. ${ }^{461}$ In perhaps the wisest remark in its opinion, the Court said:

Reliance on context and structure in statutory interpretation is a "subtle business, calling for great wariness lest what professes to be mere rendering becomes creation and attempted interpretation of legislation becomes legislation itself."

.. . But in every case we must respect the role of the

Legislature, and take care not to undo what it has done. ${ }^{462}$

Thus, the Court recognized that statutory text plays a vital role in statutory interpretation. A court is not to rewrite a statute in accordance with its understanding of wise social policy. But neither is a court to employ interpretive techniques so exacting that they destroy the legislative plan. The court is not to say to the legislature: "We know what you meant to say, but you didn't quite say it. So the message from us in the judicial branch to you in the legislative branch is: 'Gotcha! And better luck next time." "463

There will always be room for debate as to how much judicial gloss is permitted and how great a legislative drafting error a court can repair. Judgment will always be required. This is why we need judges. This is why the Supreme Court will never be replaced with an app. Statutes are created by humans; they must be interpreted by humans. The necessary degree of judgment is within the judicial power.

Justice Scalia fought long and hard to promote his interpretive methods. Although he usefully called attention to intentionalist and

461 See supra Section II.B.

462 King v. Burwell, 135 S. Ct. 2480, 2495-96 (2015) (quoting Palmer v. Massachusetts, 308 U.S. 79, 83 (1939)).

463 Russ v. State Farm Mut. Auto. Ins. Co., 961 F. Supp. 808, 820 (E.D. Pa. 1997). 
purposivist excesses, ultimately the rest of the federal judiciary was right to reject his call for adoption of the textualist ideal. "The text is the law" is a good slogan, but it is untrue. The text is usually the law, but not always. Sound statutory interpretation demands the rejection of the textualist ideal. 